NBER WORKING PAPER SERIES

\title{
THE ILLIQUIDITY PUZZLE: \\ THEORY AND EVIDENCE FROM PRIVATE EQUITY
}

\author{
Josh Lerner \\ Antoinette Schoar \\ Working Paper 9146 \\ http://www.nber.org/papers/w9146 \\ NATIONAL BUREAU OF ECONOMIC RESEARCH \\ 1050 Massachusetts Avenue \\ Cambridge, MA 02138 \\ September 2002
}

We thank a number of institutional and individual investors for making this paper possible by providing access to the limited partnership agreements in their files. Richard Testa helped us identify and access the Doriot papers discussed in Section 2. Helpful comments were provided by seminar participants at New York University, the Universities of Florida and Texas, Lucian Bebchuk, Katharina Lewellen, and David Scharfstein, and a number of practitioners, especially Allan Bufferd, Rick Burnes, Peter Dolan, Tom Lupone, Ken Morse, Sarah Reed and Kevin Tunick. Matthew Espy and especially David Schannon provided excellent research assistance. Harvard Business School's Division of Research provided fiancial support. All error and omissions are our own. The views expressed in this paper are those of the authors and not necessarily those of the National Bureau of Economic Research.

(C) 2002 by Josh Lerner and Antoinette Schoar. All rights reserved. Short sections of text, not to exceed two paragraphs, may be quoted without explicit permission provided that full credit, including (C) notice, is given to the source. 
The Illiquidity Puzzle: Theory and Evidence from Private Equity

Josh Lerner and Antoinette Schoar

NBER Working Paper No. 9146

September 2002

JEL No. G24, G32

\begin{abstract}
This paper presents a theory of liquidity where we explicitly model the liquidity of the security as a choice variable, which enables the manager raising the funds to screen for "deep pocket" investors, i.e. these that have a low likelihood of a liquidity shock. By choosing the degree of illiquidity of the security, the manager can influence the type of investors the firm will attract. The benefit of liquid investors is that they reduce the manager's cost of capital for future fund raising. If inside investors have fewer information asymmetries about the quality of the manager than the outside market, more liquid investors protect the manager from having to return to the outside market, where he would face higher cost of capital due to asymmetric information problems. We test the predictions of our model in the context of the private equity industry. Consistent with the theory, we find that transfer restrictions on investors are less common in later funds organized by the same private equity firm, where information problems are presumably less severe. Contracts involving the close-knit California venture capital community - where information on the relative performance of funds are more readily ascertained - are less likely to employ many of these provisions as well. Also, private equity partnerships whose investment focus is in industries with longer investment cycles display more transfer constraints. For example, funds focusing on the pharmaceutical industry have more constraints, while those specializing in computing and Internet investments have fewer constraints. Finally, we investigate whether the identity of the investors that invest in a private equity fund is related to the transferability of the stakes. We find that transferability constraints are less prevalent when private equity funds have limited partners that are known to have few liquidity shocks, for example endowments, foundations, and other investors with long-term commitments to private equity.
\end{abstract}

Josh Lerner

Harvard Business School

South Hall, Room 220

Boston, MA 02163

and NBER

jlerner@hbs.edu
Antoinette Schoar

Sloan School of Management

50 Memorial Drive, E52-447

Cambridge, MA 02142-1347

and NBER

aschoar@mit.edu 


\section{Introduction}

Economists have long argued that liquidity is a mixed blessing. While a publicly observable stock price may help to insure better incentives to managers and more efficient investment decisions (e.g., Scharfstein and Stein, 2000), liquidity also comes with some real costs. In a classic paper, Grossman and Hart (1980) show that highly liquid firms with dispersed shareholders may be less effectively governed, because it is difficult for an outsider shareholder to mount a profitable takeover bid. The tradeoffs between liquidity and corporate governance have been further modeled in Holmström and Tirole (1993), and Faure-Grimaud and Gromb (1999). ${ }^{1}$

This paper examines rationales for illiquidity quite distinct from the governance-based stories that have dominated the earlier literature. We motivate the analysis by considering a setting where the governance considerations are much less important, but severe restrictions on liquidity are commonplace: private equity limited partnerships. Limited partners in U.S. private equity funds typically have very limited rights and incentives to influence or direct the funds' activities. ${ }^{2}$ Even though in some cases investors can, for example, vote to dissolve the fund, this hardly ever occurs. Private equity investors, however, require wide ranging information rights which allow them to monitor the performance of the fund. Usually, investors meet with their general partners on a regular basis to discuss the progress of the portfolio firms. All the limited partners we talked to confirmed that they choose exit over voice, when they are dissatisfied with the performance of a fund. Yet serious limitations on the transferability of partnership interests - far beyond what is required by securities law - are commonplace. The presence of these curbs is particularly puzzling, since partnership interests are very illiquid to start with, due to the large stakes held by each limited partner. ${ }^{3}$

This paper explores this apparent puzzle. We present a model that explores why it might be optimal for both general and limited partners to limit the liquidity of private equity stakes. The basic idea is that these restrictions allow the managers of a private equity fund, the general partner

\footnotetext{
${ }^{1}$ These themes are also developed in Shleifer and Vishny (1986). Bhide (1993) represents a less formal treatment of the tradeoff between liquidity and governance.

${ }^{2}$ At least in part, this reluctance is rooted in the Uniform Limited Partnership Act, which links the shielding of the limited partners from liability for the partnership's activities to their non-involvement in the day-to-day management of the fund.

${ }^{3}$ In fact, recently there have been a number of attempts in the investment banking community to issue debt-like securities that are backed by private equity returns to circumvent these constraints.
} 
(GP), to screen for limited partners (LPs) with long horizons. By explicitly choosing the degree of illiquidity of the fund, the GP can influence the type of investors the fund will attract. A limited partner who expects to face many liquidity shocks would find these restrictions especially onerous and therefore, would avoid investing. This guarantees the GP a pool of limited partners who are especially liquid. Liquid limited partners reduce the GP's cost of capital for future fund raising, because these inside investors have fewer information asymmetries about the quality of the GP than the outside market. Therefore, the GP reduces the likelihood of having to raise capital in the outside market where he faces higher capital costs, since the market cannot distinguish whether the initial investors truly faced a liquidity shock or whether the fund is a "lemon." 4 Transfer constraints de facto allow the GP to trade off increased cost of capital in early funds against lower cost in future funds by minimizing the lemons problem with respect to the outside market. We also show that if venture capitalists and limited partners bargain over rents in follow-on funds, the "deep pocket" limited partners always prefer that funds have transfer constraints, since these increase their bargaining power relative to the venture capitalist.

The novel contribution of our model is that we analyze illiquidity as a choice variable, which can be influenced by the general partner and allows him to screen for "deep pocket" investors. Thus, illiquidity here is not the symptom of an underlying asymmetric information problem as it is in most of the asset pricing literature on liquidity. Instead, we model illiquidity as an outcome of the general partners' optimization problem. It is important to point out that the intuition of our model is driven by the information asymmetry between inside and outside investors and not by the fact that a private equity fund might face large transaction costs if it was forced to liquidate prematurely. The transfer of equity stakes is independent of the capital commitment to the fund.

We believe that this is a general phenomenon, which applies to a number of situations of security design, including other private partnerships like real estate investment funds and even private placements of public companies. These so called PIPE transactions involve a public company raising capital from a private investor, often a hedge fund. But even outside of private equity there are many financing situations where this intuition has relevance. Take for example a biotech startup which has the choice of either undertaking an IPO or raising capital in a strategic alliance with a

\footnotetext{
${ }^{4}$ One could imagine a number of different ways to motivate why limited partners face liquidity shocks. One might be true lack of capital. Alternatively, especially pension funds might have internal agency or capital allocation rules that lead to changes in their commitment to the private equity asset class over time.
} 
large pharmaceutical company. Obviously the former solution provides lower cost of capital in the short run, if the IPO market is hot. But one of the reasons why we observe the large dependence on strategic alliances in biotechnology might be that start-ups want to secure very liquid investors with long horizons.

We then turn to an empirical examination of the testable predictions of our theory based on a sample of about 250 private equity partnership agreements. We show that, consistent with the model, these restrictions on limited partners' ability to transfer funds are less common in later funds organized by the same venture group, where information problems are presumably less severe. Also, private equity partnerships whose investment focus is in industries with longer investment cycles display more transfer constraints. Funds that invest in businesses which take a long time before they produce observable results are prone to increased information asymmetry. In congruence with our theory, these funds are more concerned about preventing transfers of equity stakes. For example, we find that funds specializing in the pharmaceutical industry have more transfer constraints, while those focused on computing and Internet have fewer constraints. We argue that these findings are consistent with the idea that in situations where asymmetric information problems are more severe for future fund raising, there will be more emphasis on selecting long-horizon investors. Another interesting finding is that contracts by California venture capital partnerships are much less likely to employ many restrictive provisions. On interpretation of this result is that in the close-knit California venture community information on the relative performance of funds may be more readily ascertained. Finally, we investigate whether the identity of the LPs that invest in a private equity fund is related to the transferability of the stakes. In line with the predictions from our model, we find that transferability constraints are less prevalent when private equity funds have limited partners that are known to have few liquidity shocks. For example, we find that funds that have a high fraction of endowments, foundations, and other investors with a long-term commitment to private equity among their limited partners also impose fewer transfer constraints. Again, this evidence is in line with our theoretical prediction that in situations where liquidity shocks are less important for the limited partners, there is reduced need for transfer constraints. We are cautious to stress, however, that these results should only be seen as suggestive evidence for of our model.

The most obvious alternative story for imposing transfer constraints would be that GPs have preferences about which investors they like to deal with and therefore want to be in control of 
transfers. In this case, transfer constraints would be a reflection of the bargaining power of GPs and LPs. Once a GP has established a superior track record, however, he should have more bargaining power relative to the investors and therefore demand more transfer constraints. But we find that older and more established partnerships impose less constraints on their LPs, which seems to support the information-based story that we propose in this paper.

The plan of the paper is as follows. The second section considers the institutional setting of private equity, and discusses an illustrative case. We present the model in Section 3. Section 4 discusses the data and the analysis of private equity contracts. Section 5 looks at the composition of limited partners of these private equity funds. The final section concludes the paper.

\section{Institutional Setting}

We suggest in the introduction that private equity is an environment to examine the costs and benefits of liquidity as a screening mechanism, as it presents a setting where the traditional rationale for illiquidity - the need for governance - is not present. This section discusses this setting at greater length.

Private equity funds typically are raised in the form of limited partnerships. Unlike corporations, these partnerships have finite lives, typically ten years though extensions of a few years may be possible. The general partners (the private equity fund's professionals) invest the capital raised from limited partners, typically large institutional and individual investors, in entrepreneurial or restructuring funds. The investment focus will depend on the fund's mandate, which is defined in the partnership agreement governing the fund. After the firms go public or are sold, the proceeds (whether in the form of equity or cash) are divided between the limited and general partners, leading to a close alignment of the incentives of the two parties. For a more detailed discussion of private equity funds, see Gompers and Lerner (1999b).

Conversations with limited and general partners of private equity funds suggest that the restrictions on the transferability of limited partnership interests are motivated in large part by the adverse effects that such transfers can have on the operations of the funds. The recurring theme that we heard when talking to practitioners is that GPs want to avoid partnership stakes ending up in the hands of unsophisticated investors without a long-term commitment to the asset class, 
which is in line with the argument of this paper. A number of the seasoned practitioners pointed to the experience of the early private equity funds: most funds were freely tradable between the $1940 \mathrm{~s}$ and $1960 \mathrm{~s} .{ }^{5}$

A review of historical materials regarding the pioneering venture capital fund American Research and Development $(\mathrm{ARD})^{6}$ suggests that the liquidity of the fund had a number of adverse effects:

1. Raising additional capital proved to be highly dillutive for existing shareholders. For instance, when ARD sought to raise additional capital in 1958 to finance their investment in Digital Equipment Corporation (which ultimately accounted for the majority of their portfolio's gains), they were required to sell shares at a price that was nearly $40 \%$ below the fund's net asset value (and even further below the fund's true value).

2. When investors in the fund sought to liquidate their positions, these moves caused grave concerns for the venture capitalists. For instance, when American Express sought to sell its ARD holdings in 1948 due to a change in its investment policy, the fund's partners grew concerned that it would have a negative effect on the share price. The fund arranged to buy the block of shares from American Express directly, even though the move substantially depleted the fund's remaining uninvested capital.

By way of contrast, we did not hear any support for a governance-based explanation of why transfer constraints exist. Usually, this does not constitute an important consideration for private equity limited partners for two reasons. The first reason reflects the nature of the assets held by these funds. Investments by private equity funds are typically highly illiquid, and difficult to salvage for an attractive price. Thus, even if the limited partners were to step in and force a liquidation of a fund, they would be unlikely to get much of a return for their effort. This lack of active involvement in the funds day-to-day activities, however, does not preclude the limited partners from gathering important information about the quality and performance of the general partners running the fund. GPs usually report to their LPs quarterly in written form and annually

\footnotetext{
${ }^{5}$ These early funds were typically structured as closed-end funds or corporations, rather than as limited partnerships. The choice of this structure was based not on choice but rather necessity, because these pioneering funds found it very difficult to access capital from institutional sources. Instead, they often turned to investment banks to raise the needed funds from retail investors through public offerings.

${ }^{6}$ This discussion is based on Capital Publishing Company (various years), Liles (1977), and the Georges Doriot collections in the archives of Baker Library and the French Library and Cultural Center of Boston.
} 
in person about the investments the fund has made as well as the ongoing investments that the partnership has in its portfolio. This interaction allows the LPs to develop an informed opinion about the quality of the partnership and its general partners. If the partnership turns out to be of low quality, LPs will frequently simply wait until the appointed life of the fund is reached, and avoid investing in any further funds organized by the problematic organization.

The second rationale for transfer constraints is legal. The Uniform Limited Partnership Act (U.L.P.A.), which has been enacted in its original or revised form in 48 of the 50 states (Harroch, 1998), restricts the ability of limited partners to become involved with the day-to-day operations of the fund. Under this act, the limited partner's liability is limited to the amount of capital contributed to the partnership, as long as that partner does not "participate in the control of the business." 7 As a result, limited partners who exercise supervisory authority or other management control over the partnerships in which they invest may endanger their limited liability status, a grave concern for any investor. As a result, limited partners have avoided playing an active role in the governance of private equity funds. ${ }^{8}$

Finally, securities and tax regulations certainly play a role in the decision to restrict the transferability of limited partnership interests. Funds try to avoid coming under the provisions of the Investment Company Act of 1940, which imposes costly disclosure requirements on the GPs. Similarly, if the stakes of a limited partnership were freely traded, the fund would be taxed at the partnership as well as the LP level, which would be especially detrimental since many investors of private equity funds are tax-exempt entities. Most practitioners and legal scholars agree, however, that the level of control over transfer constraints imposed in most partnership agreements are far in excess of what would be required to comply with securities and tax law. Please refer to the Appendix for a detailed discussion of the tax implications and legal constraints affecting limited partnerships.

\footnotetext{
${ }^{7}$ Revised Uniform Limited Partnership Act $303($ a). The U.L.P.A. uses the phrase "take part."

${ }^{8}$ For a discussion of these issues, see Burr (1982) and Feld (1969). These strictures may be relaxed by the creation of limited liability corporations (LLCs), hybrid structures that were first introduced in 1977 . Given the novelty of these structures and the size of the potential downside, limited partners have been reluctant to assume a more active governance role, even in funds organized as LLCs.
} 


\section{A Model of Transferability Restrictions in Private Equity}

Why would a venture capitalist place restrictions on the transferability of partnership stakes? On their face, such restrictions reduce the liquidity of these stakes and should therefore diminish their value, since limited partners, even very liquid ones, need to be compensated for this lack of liquidity. In this section, we propose a simple model that explains why a venture capitalist can actually benefit from such restrictions in the long run, even though they may in the very short run reduce value by having to pay a liquidity premium to investors.

The basic idea is that transfer restrictions are used to screen for limited partners with long horizons. Imagine that LPs differ in their likelihood to face liquidity shocks and thus in their likelihood of being forced to sell their partnership stakes. An LP with a higher propensity to have a liquidity shock would find these restrictions especially onerous and, therefore, would be less inclined to invest in these funds than one with a lower likelihood of a liquidity shock, every thing else equal. By imposing these restrictions in the first place, the GP is guaranteed a pool of LPs that are especially liquid.

Liquid limited partners are beneficial for the GP because of the repeated game nature of the fund raising process. GPs normally raise new funds every few years. If the GP has investors with "deep pockets," he will not need to go back to the capital market for future fundraising. The GP trades off the current cost of equity against the benefits from insuring future access to the capital market. As we will show, the higher the benefits from raising a follow-on fund, the more this tradeoff tilts in the direction of imposing transfer constraints everything else equal. Most general partners agree that there are very large private benefits from running ones own fund, not only financially. The alternative employment opportunities of a GP who fails to raise another fund are considerably less desirable than the status quo, e.g. they usually accept a junior role in other funds or join a start-up company.

We assume that incumbent investors learn inside information about the quality of the fund during their time of involvement with the venture capitalist. Therefore, they are natural candidates to invest in the GP's next fund, if the GP turns out to be a high type. This assumption is very intuitive in the context of private equity funds, since many funds do not have realized returns by the time the partnership raises a follow-on fund. The lack of a market price for the underlying assets makes it difficult to communicate the quality of the general partners to an outsider. By attending 
partnership meetings, observing the funds' changing strategies, and assessing entrepreneurs that they have financed, limited partners gain much tacit information about the quality of the private equity firm that a simple review of a private placement memorandum would not provide.

As a consequence, the GP faces an adverse selection problem in the outside market. If an incumbent limited partner has a liquidity shock, the GP is forced to go to outside investors. These outsiders will wonder why incumbent investors passed on the new fund. They cannot differentiate whether the incumbent investors passed because of liquidity reasons or because the fund is a "lemon". Therefore, outside investors will charge a higher cost of capital than an insider who knows the quality of the GP. This makes liquidity shocks very costly to the GP, since he will get penalized as if the new fund were a "lemon".

This assumption, which we believe accurately describes the private equity fundraising process, provides the central source of asymmetric information that drives our model. These partnerships as well as their LPs are very protective about internal information of the funds. Often private equity partnerships will not give out the names of their prior (or even their current) limited partners. Of course, this makes it very difficult to assess the signal content, when a partnership is forced to raise capital from the outside market. Even for LPs that are more in the public eye, e.g., pension funds or corporate investors, it is often very difficult for an outsider to ascertain whether they are passing due to a lack of liquidity or due to inside information, since these funds have complex liability and allocation rules. Moreover, most LPs do not publicize their decisions to cease investing in a private equity group, instead terminating the relationship quietly. ${ }^{9}$

Note that we also rule out strategic behavior of the general partner in the first period by assuming that his quality is unknown to the investors as well as to the GP himself. This assumption is supported by many observers of the venture capital fundraising cycle. Even GPs that have long and successful track records as entrepreneurs or managers in established companies prior to joining (or raising) a fund, often struggle to succeed in private equity. Moreover, a recent paper by Gompers

\footnotetext{
${ }^{9}$ An extension of the model that has been suggested could be to introduce heterogeneity in the level sophistication of the limited partners. If "deep pocket" investors are also better at differentiating high quality venture capitalists from low quality ones, more liquid LPs might select better funds. This approach would only undo the logic of our model, however, if the correlation between "deep pockets" and information was one-for-one and if there is no noise in the limited partner's ability to screen private equity funds. In this extreme case, liquid LPs select the best funds and lower quality funds are left with less sophisticated (and, according to this assumption, more illiquid) investors. Thus, in equilibrium there would be no need for screening by the private equity funds. Since we do not feel that this is an economically meaningful assumption, we abstract from this extension for notational ease.
} 
and Lerner (1999a) explicitly tests whether venture capitalists have private information about their quality or not. The paper finds evidence that is consistent with a model where venture capitalists do not possess private information about their own type ex ante. Finally, even if we assume that GPs have private information about their type, it does not seem obvious why they would use transfer constraints as a signaling or sorting device. It seems more natural that high types would use the structure of compensation to separate themselves from the low types.

In sum, by limiting the fund to the most liquid investors, the GP can reduce the likelihood of having to go back to the outside market. This strategy, however, also entails two costs. First, even the most liquid investors may need to be compensated for holding illiquid stakes and will require a liquidity premium. Second, in the rare event that these liquid investors do face a liquidity crisis, the market will especially penalize the GP. Outside investors will see that the fund imposes transfer constraints and thus has very liquid investors. If these LPs have chosen to pass on the new fund, it aggravates the market's concern that the fund is a lemon. When imposing liquidity constraints, the GP has to trade off these costs against the benefits from having liquid investors. In the context of our model, we will show under which circumstances it is optimal for the GP to reduce transferability of the stakes.

\subsection{Setup}

Our model has two players: a general partner (GP) and a limited partner (LP). While we only model a single LP for simplicity, we will be implicitly assuming that there are many LPs and, therefore, the GP has all the bargaining power. ${ }^{10}$ In Section 3.4, we extend the model to allow for Nash bargaining in the second round.

The GP wants to raise a fixed amount of capital $I$ to finance a first fund. Since we are interested in how screening for investors affects future costs of capital, we will assume he plans to raise a second fund in the future. There are two types of venture capitalist in the population, a good type (with probability $p$ ) and a bad type (with probability $1-p$ ). A good venture capitalist's fund will be

\footnotetext{
${ }^{10}$ Formally including all these partners produces equivalent results, but severely complicates notation. The key difference is that in a scenario with several LPs, the existing LPs could step in to buy the share of an LP that faces a liquidity shock. The logic of our model would be unchanged, however, since the GP in the first period still has the incentive to insure that at least a sufficient subset of the LPs are very liquid to avoid having to raise funds from the outside market. In practice LPs, especially pension funds, often have tight restrictions on how much they can invest in each individual private equity fund and therefore cannot have too much exposure in a single fund.
} 
worth $V_{G}>0$, whereas a bad venture capitalist's fund will be worth 0 . Both types receive a private benefit from running the fund of $B$. This guarantees that even if the venture capitalist knew that he was a bad type, he would choose to raise a new fund.

Since $I$ dollars need to be raised, the GP and the LP must agree on what fraction of the firm, $\pi$, the LP will receive in return for her $I$ dollars of investment. ${ }^{11}$ LPs also come in two types. Illiquid LPs (who occur with probability $q$ ) face a liquidity shock with probability $\lambda_{1}$ and liquid ones (probability $1-q$ ) face it with probability $\lambda_{2}<\lambda_{1}$. A liquidity shock means the investor must sell her shares (or cannot invest in new shares); otherwise, she will incur a cost $c$. For simplicity we normalize the interest rate in the market to be zero.

The model takes place over four periods.

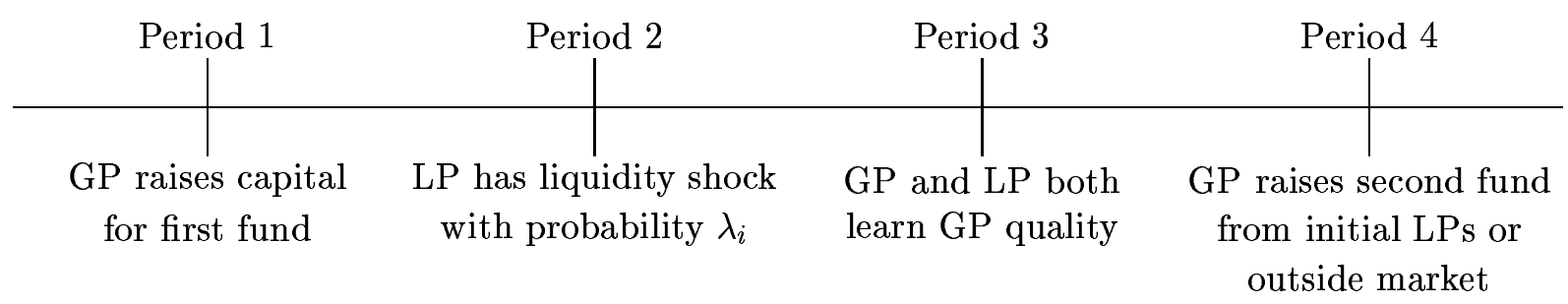

Figure 1: Timeline

1. In the first period, the GP raises money for the first fund. At this point, the GP and the LP agree on the share $\pi_{1}$ that the LP will receive in exchange for her investment. As noted earlier, the GP will have all the bargaining power. At this point, the type of the GP is unknown to both parties, but whether the investor is liquid or illiquid is known to the LP but not to the GP.

2. In the second period, the investor may face a liquidity shock. Since at this point, she does not know yet whether the fund she has invested in is a good fund or a bad fund, she faces no

\footnotetext{
${ }^{11}$ In actuality, the GP and the investors will bargain over the carried interest and management fee that the GP will receive. Here, we model this as bargaining over the fraction of the value received by the investors for expositional simplicity.
} 
lemons problem when trying to sell the stake.

3. In the third period, both parties learn the type of the GP. With probability $p$, the general partner is a good type.

4. Subsequently, in the last period a new fund is raised. The GP may either go to outside markets to raise funds or may rely on incumbent investors, depending on their liquidity and his type. The cost of capital in this period will be called $\pi_{2}^{M}$ if he goes to the market and $\pi_{2}^{I}$ if incumbent investors finance the next fund. Again, the GP has all the bargaining power in this period. ${ }^{12}$

\subsection{Solving the Model}

Now the GP's optimization problem is to maximize his profits from both funds. He has to choose whether he will impose a liquidity constraint in the first period or not. Therefore, we solve the model by computing profits with and without restrictions and then comparing the two scenarios. In both cases, we will work backwards in time, considering the last period cost of capital and then considering the first period.

\subsubsection{No Restriction}

If the GP places no restriction, he will raise funds from both types of LPs, liquid and illiquid ones. ${ }^{13}$ In the second period, the GP's cost of capital will depend on whether he is a good type or a bad type. If he is known to be a good type, the incumbent investor is willing to invest at the cost of capital:

$$
\pi_{2}^{I}=\frac{I}{V_{G}}
$$

If the incumbent investor receives a liquidity shock, the GP must go to the market to raise his next fund. Similarly, the GP will be forced to go to the market, if he turns out to be a bad

\footnotetext{
${ }^{12}$ For simplicity, we do not consider whether there are future liquidity shocks affecting the new set of investors and how that impacts the next round of fund raising and so on. The intuition is merely a replay of the current model.

${ }^{13}$ For simplicity, we assume that the GP has no other non-price instrument to screen between investors. One could imagine that there are additional ways to separate investors, e.g. conducting careful due diligence on the investors. We abstract from these measures in this paper, since they do not conflict with the logic of the mechanism that we want to highlight. We will discuss the possibility of using the price as a mechanism to separate investors at the end of this section.
} 
type, since the inside investors will not be willing to reinvest in this case. Since the market cannot differentiate between these two cases, it will charge a lemons premium in both cases. ${ }^{14}$

The cost of capital for the GP now is:

$$
\pi_{2}^{M N}=\frac{I\left[\left(q \lambda_{1}+(1-q) \lambda_{2}\right) p+(1-p)\right]}{\left(q \lambda_{1}+(1-q) \lambda_{2}\right) p V_{G}}
$$

In the first period, the GP faces a cost of capital independent of his type since it is unknown:

$$
\pi_{1}^{N}=\frac{I}{V_{G} p}
$$

Therefore, the GP's overall profits are:

$$
\begin{aligned}
& V_{G} p-I+B \\
+ & p\left[\left(1-\lambda_{1}\right) q+\left(1-\lambda_{2}\right)(1-q)\right]\left(B+\left(V_{G}-I\right)\right) \\
+ & p\left[\lambda_{1} q+\lambda_{2}(1-q)\right]\left(B+V_{G}-\frac{I\left[\left(q \lambda_{1}+(1-q) \lambda_{2}\right) p+(1-p)\right]}{\left(q \lambda_{1}+(1-q) \lambda_{2}\right) p}\right) \\
+ & (1-p) B
\end{aligned}
$$

Each of these terms is easy to interpret. The first term is the expected profit plus private benefits for the first period. The second term is the profit plus private benefits if the GP turns out to be good (probability $p$ ) and the incumbent investor does not have a liquidity shock (probability $\left.\left(1-\lambda_{1}\right) q+\left(1-\lambda_{2}\right)(1-q)\right)$. The third line describes the profits if the GP is good but the incumbent investor gets a liquidity shock (probability $\lambda_{1} q+\lambda_{2}(1-q)$ ), forcing the GP to go to the market. The final term is the payoff if the GP turns out to be bad and has to go to the market. Notice he will only receive the private benefits since the project will be worth nothing.

\subsubsection{With Restriction}

Now let us analyze the case when the GP imposes transfer restrictions in the first period. We model this as inflicting a cost $c$ whenever the LP wants to sell. ${ }^{15}$ Then LPs with low probability

\footnotetext{
${ }^{14}$ We assume that the market is willing to provide financing when GPs have to come back to outside investors. If the pool of bad types in the population is very large, the lemons problem could be so large as to preclude GPs from obtaining financing in the outside market. In this case, the importance of transfer constraints would be even more pronounced, since the market now becomes inaccessible to the venture capitalist after the incumbent LP has a liquidity shock.

${ }^{15}$ We can think of this cost as the transaction costs involved when the limited partner wants to sell her stake. Alternatively, these costs can be interpreted as the utility cost to an LP who is forced to hold the private equity stakes when her outside need for capital is very high.
} 
of a liquidity shock will be more inclined to invest in the fund. Again, the cost of capital in the second period will depend on the GP's type. If he is a good type and the LP did not face a liquidity shock, the cost of capital is:

$$
\pi_{2}^{I}=\frac{I}{V_{G}}
$$

This is parallel to the case with no restriction, but note that the probability of obtaining financing from insiders is now higher, since the GP has screened out the illiquid LPs.

Again, there are two cases when the GP needs to raise funds from the outside market; either he is a bad type or the inside investor has a liquidity shock. In this case his cost of capital is:

$$
\pi_{2}^{M R}=\frac{I\left[\lambda_{2} p+(1-p)\right]}{\lambda_{2} p V_{G}}
$$

Note that the cost of capital in the outside market is now much higher than in the case with no restrictions. The market knows that the LP has a low probability of a liquidity shock and thus puts more weight on the possibility that the GP is a bad type. ${ }^{16}$

If the liquid LP has a very low likelihood of facing a liquidity shock $\left(\lambda_{2}<\frac{I(1-p)}{\left(V_{G}-I\right) p}\right)$, now it becomes impossible for the GP to raise any follow-on financing from the outside market. The market now will think that almost surely the GP must be a bad type, when the inside investor passes on the next fund. Here we analyze the case where the GP is unable to obtain financing from the outside market. In the first period, the GP's cost of capital is equal to the case with no restrictions:

$$
\pi_{1}^{N}=\frac{I}{V_{G} p}
$$

Now the GP's overall profits are:

$$
\begin{aligned}
& V_{G} p-I+B-\lambda_{2} c \\
+ & p\left(1-\lambda_{2}\right)\left(B+\left(V_{G}-I\right)\right) \\
+ & p \lambda_{2}(0) \\
+ & 0
\end{aligned}
$$

\footnotetext{
${ }^{16}$ Alternatively, we could imagine that the outside market has no way of knowing the composition of the limited partners that invested in the first period. In this case, the venture capitalist who imposed transfer constraints in the first fund faces the same cost of capital when he has to go to the market as a fund that did not screen for liquid investors, since the market cannot differentiate between them. This simplifies the trade-off for the GP: he only trades off a liquidity premium in the first period with reduced likelihood of having to go to the market in the second, when he imposes constraints. The results are qualitatively unchanged but imposing transfer constraints is more attractive.
} 
Each of these terms is parallel to the case with no restrictions. The first term is the expected profit plus private benefits in the first period, minus the liquidity premium that the GP has to pay the limited partners for incurring the transfer restrictions. The second term is the profit plus the private benefits if the GP turns out to be good (probability $p$ ) and the incumbent investor does not have a liquidity shock (probability $\left(1-\lambda_{2}\right)$ ). Because the transfer restrictions screen out investors with high frequency of liquidity shocks, the probability of achieving insider financing in the second period is much higher than in the case with no restrictions. This constitutes the benefits of imposing transferability constraints. In contrast, the third and fourth lines show the costs of transferability constraints. The GP's profits are zero if he is a good type but the incumbent investor gets a liquidity shock (probability $\lambda_{2} p$ ), since he cannot get any financing from the outside market. Notice that the GP also foregoes his private benefits since he cannot obtain financing for a follow-on fund.

\subsection{When is it Profitable to Impose Transfer Restrictions?}

The difference in profits when there is a restriction relative to when there is none is:

$$
(1-p)[I-B]-\lambda_{2} c-p \lambda_{2}\left(B+V_{G}-I\right)
$$

Each of these terms is intuitive. The first term reflects the benefits of having liquid investors. If the GP turns out to be good, then he benefits from having a reduced probability of a liquidity shock. The second term is the liquidity premium. The liquid investor still faces a shock with probability $\lambda_{2}$, so she will need to have her initial investment cover this shock. The third term reflects the worsening of the lemons problem in the outside market caused by the restriction. Since in this case, the problem gets severe enough that the GP cannot borrow at all, this third term equals the foregone benefits of being able to raise capital at all.

There are several things to note here. First, the above result only depends on $\lambda_{2}$, the likelihood that the liquid investor receives a liquidity shock, but not on $\lambda_{1}$, the likelihood that the illiquid investor receives a liquidity shock. $\lambda_{1}$ does not enter the result, since the benefits of imposing transfer restrictions (and thus only having liquid investors, $\lambda_{2}$ ) are calculated relative to the benchmark case when both types of LPs invest. Second, consider the following comparative statics. Suppose that the private benefits of control are small $(\mathrm{B} \rightarrow 0)$ and that the liquid investor rarely receives 
liquidity shocks $\left(\lambda_{2} \rightarrow 0\right)$. This makes the costs of placing a transfer restriction small and also increases the benefit of the restriction. Thus, in this case the GP will want to impose a restriction. Alternatively, imagine that the pool of LPs is composed mainly of liquid investors $(q \rightarrow 0)$. Then it will be unprofitable to place a restriction: there are few illiquid investors to screen out but the GP would still have to pay the liquidity premium $\left(\lambda_{2} c\right)$. Similarly if all GPs were high types $(p \rightarrow 1)$, placing a restriction would be unprofitable. These comparative statics underscore the rationale for restrictions: by serving to screen for liquid investors, they reduce the adverse selection problem faced by the GP in raising funds in the second period.

\subsection{Bargaining over Returns in the Second Period}

In the analysis until now we have assumed that the GP has all the bargaining power in the first and second periods, while the LP just breaks even on the investment. We will now extend the model to assume that inside LPs have bargaining power in the negotiation about division of profits in the follow-on fund. ${ }^{17}$ This assumption is realistic given our understanding of the venture capital fundraising process. Moreover, we assume that there is non-contractibility in period one over the returns in the follow-on fund. This assumption seems justified, since there is little commitment between funds. In fact, we often see provisions prohibiting cross-subsidization between funds. First, allowing cross investments between funds would distort the GP's incentives. Second, the composition of limited partners changes between funds and therefore makes it difficult to allow certain LPs to hold options on the next fund. ${ }^{18}$

Incumbent LPs will invest in a GP's follow-on fund if he is a high type. At that point the required equity stake for the incumbent LP is $\pi_{2}^{I}=\frac{I}{V_{G}}$, since she know the GP's (high) type. The outside cost of capital to the GP is higher, however, since he faces a lemons problem with respect to the outside market, as discussed above. If the inside investor threatens not to reinvest, the GP would have to go to the outside market, where he faces a cost of capital of $\pi_{2}^{M N}=\frac{I\left[\left(q \lambda_{1}+(1-q) \lambda_{2}\right) p+(1-p)\right]}{\left(q \lambda_{1}+(1-q) \lambda_{2}\right) p V_{G}}$

\footnotetext{
${ }^{17}$ To keep the notation simple we do not consider bargaining in the first period, since it does not contribute the economic intuition of the model.

${ }^{18}$ If the parties could contract over returns in later funds, the GP could use the price mechanism to screen for "deep pocket" investors instead of having to resort to transfer constraints. Since "deep pocket" investors have a higher probability to reinvest and thus to earn rents from the second fund, they would be willing to accept a smaller equity stake in exchange for their investment in period one. This would allow the GP to achieve separation without having to resort to transfer restrictions. This mechanism would only work, however, if the probability of good GPs was high enough to generate a positive expected value from investing in future funds.
} 
if he did not impose transfer constraints in the first period (and $\pi_{2}^{M R}=\frac{I\left[\lambda_{2} p+(1-p)\right]}{\lambda_{2} p V_{G}}$, if he did).

We assume that the GP and the LP will split the difference between the outside and inside cost of capital via Nash bargaining. Therefore, the LP earns rents of $0.5\left(\pi_{2}^{M N}-\pi_{2}^{I}\right)$ from the second fund (she earns $0.5\left(\pi_{2}^{M R}-\pi_{2}^{I}\right)$, respectively, if the GP did impose transfer constraints in the first period). It is important to note that when GP and LP bargain over rents, the "deep pocket" limited partner $\left(\lambda_{2}\right)$ always prefers that the GP imposes transfer constraints in the first period. As we discussed before, imposing transfer constraints worsens the adverse selection problem with respect to the outside market, which in turn improves the threat point for the incumbent LP. Since the GP would incur very high costs in the outside market (or in extreme cases might even be precluded from accessing the outside market), the LP threatens not to reinvest at all. This allows her to extract more rents from the GP in the follow-on fund.

The derivation of the GP's optimization problem with bargaining is parallel to the analysis above. Therefore, we will only focus on final comparison of when it is profitable for the GP to impose transfer restrictions. The difference in profits when there is a restriction relative to when there is none now becomes:

$$
(1-p)[I-B]-\lambda_{2} c-p \lambda_{2}\left(B+V_{G}-I\right)+0.5 I(1-p) q \frac{\lambda_{2}-\lambda_{1}}{\left[q \lambda_{1}+(1-q) \lambda_{2}\right] \lambda_{2}}
$$

This expression is identical to the result in Section 3.3 except for the last term. The first three terms present the GP's gains from avoiding the adverse selection problem in the outside market and the worsening of the adverse selection problem, if he does have to go to the outside market. But now there is one more cost that the GP has to take into account when deciding whether to impose restrictions. The GP's bargaining position with respect to his inside investors worsens, when he imposes constraints, because he reduces his outside threat point (as outside investors perceive a bigger lemons problem for the fund they will charge more to finance a next round fund). Consequently the last term is always negative (since $\lambda_{2}<\lambda_{1}$ ). In contrast, "deep pocket" limited partners always prefer transfer constraints, since it allows them to extract more rents from the GP in the second fund. 


\section{Empirical Analysis}

We now seek to examine the predictions from our model empirically, using a sample of limited partnership agreements. We find evidence that is consistent with the theoretical suggestions above.

\subsection{Data}

The sample consists of 250 private equity funds whose partnership agreements we were able to access and analyze. Since these documents are not publicly accessible, we rely on the collections of a number of institutional and individual investors. Because we wish to avoid undesirable heterogeneity (e.g., the impact of other nations' securities laws), we eliminated funds that were not U.S.-based private equity partnerships focusing on venture capital, buyout, or mezzanine investments. Gompers and Lerner (1996) uses a subset of these partnership contracts to analyze how the use of covenants restricts the behavior of general partners.

We collect a variety of supplemental information from other sources. We determined the age of the private equity organization, the location of its primary office, and the number of previous funds from Asset Alternatives (2001) and Venture Economics (1995, 2001). We also ascertain this information from the private placement memoranda used to raise these funds. For a fraction of the funds, we are able to determine the identity of the limited partners in these fund from the "Fund Raising Round-Up" section of the Private Equity Analyst.

The partnership agreements we collected were diverse. Some limited partners were very established private equity investors, who had access to some of the most prestigious funds in the industry. Other limited partners were less established, and consequently, tended to invest in younger and less prestigious private equity organizations.

As Table 1 reports, our sample contains funds that were formed between 1974 and 2001, with the mean being 1992. While the emphasis on later partnerships in part was a consequence of the greater ease of collecting documentation on more recent funds, it also reflected the rapid growth of the private equity industry in recent years. Considerable heterogeneity also existed in the size of the funds raised and their focus (approximately 20 percent of the funds were devoted to buyout investing, and another 20 percent exclusively to early-stage venture investing). Moreover, 35 percent

of the funds were based in California, while 40 percent were in the two East Coast states with the 
greatest private equity concentrations (Massachusetts and New York). Lastly, we see that funds have different industry foci. We collect this information from the above mentioned sources as well as the web sites of the individual private equity partnerships based on what the firms themselves report as their industry focus. We classify a number of main industries: pharmaceutical industry (which largely consists of biotechnology investments), telecommunications, business services, and computing/Internet. This diversity allows us to analyze how fund-specific characteristics relate to the transferability of partnership interests, and even whether the nature of the limited partners affects the liquidity of the partnership stakes.

\subsection{Descriptive Statistics}

Table 2 provides an overview of the many different contract provisions that private equity firms use to restrict potential transfers of partnership stakes or the nature of the transferee. Most strikingly, almost 90 percent of the funds in our sample require that the "general partner must approve of the transfer," which effectively allows the general partners to prevent any transfer that conflicts with their interests. If there are, however, specific exemptions that allow LPs to transfer stakes (as discussed in the next paragraph), these contingencies overwrite the GP's need for approval.

Additionally, there are a large number of provisions that fall into one of three broad classes. First, most partnership contracts include several provisions that explicitly allow the transfer of stakes to certain kinds of investors or in specific, well-defined circumstances. For example, 36 percent of the contracts stipulate that transfers are allowed to sophisticated investors, 43 percent of the funds allow the transfer to family members, and 28 percent permit the transfer of stakes to other limited partners. Other, more customized provisions include the permission to sell partnership shares after bankruptcy (in 3 percent of the funds) or to a spouse after divorce, in 13 percent. ${ }^{19}$

Second, many partnership contracts contain detailed provisions controlling the actual process by which shares can get sold. For example, about 10 percent of our funds have restrictions on the number of potential investors that can buy a partnership stake in the secondary market. We also find that about 30 percent of the funds require that the limited partner's entire share has to be sold in any transaction or that stakes can be sold to at most one person.

Finally, the third set of restrictions reflects the private equity firms' regulatory environment.

\footnotetext{
${ }^{19}$ It is interesting to note that the latter provision is mainly found in California-based partnerships.
} 
Table 2 shows that in the majority of partnership agreements, transfers cannot add regulatory and tax requirements, or lead to a termination of the partnership. These curbs are due to concerns with the Investment Company Act of 1940 and other securities legislation. ${ }^{20}$

\subsection{Constructing Composite Measures}

The descriptive statistics document the complexity of the contract terms. It would be misleading to analyze each of these contract provisions separately, since no one single term governs the transferability of limited partnership interests by itself. Rather, as the descriptive statistics suggest, a variety of terms are employed. Thus, to assess the extent to which the agreements either facilitate or hinder the transfer of limited partnership interests, we focus on a number of different composite measures that aggregate the information in the partnership agreements. We seek to quantify the various ways in which transfers by limited partners are restricted by the partnership agreements. The composite measures we employ take several forms.

Table 2 shows which provisions are included in these composite measures. First, we add all relevant terms, giving a +1 score for terms that enhance the transferability of limited partnership interests or otherwise protect the interests of the limited partners, -1 for terms that limit transfers, and 0 if such a term is not included. The second measure simply sums up the most direct provisions: the number of different types of investors to whom the limited partners are allowed to transfer their interests. The next measure is the sum of the three contract provisions that most explicitly give the general partners the ability to control the liquidity of partnership interests. Specifically, these are the requirements that the general partner approve the transfer, that the general partner approve of the limited partner status of the transferee, and that any transfer cannot conflict with the general partner's interests. The final measure, which we call complexity, summarizes all the contract provisions regarding transferability, no matter whether they enhance the LP's or the GP's prerogatives. This measure is intended to capture the level of detail and intricacy with which general partners and limited partners address this issue.

Table 2 summarizes the four variables analyzed in the remainder of this section. The frequency

\footnotetext{
${ }^{20}$ We want to point out one potential source of measurement error in our data. In some cases very powerful limited partners might obtain side letters from their private equity funds that grant them certain exemptions. Unfortunately, it is virtually impossible to collect information about these side deals. Our intuition, however, is that this should not affect our data too much. These limited partners are normally the ones where there is no need for screening liquidity.
} 
of each contractual term is reported in the first column of the table. The second through fifth columns indicate whether a term is employed in each of the four independent variables constructed here, and if it is regarded as a positive or negative contribution to the total. ${ }^{21}$

\subsection{Estimation Strategy}

The model we developed in Section 4 generates a number of testable predictions. A central argument of our theory is that limited partnerships should be most concerned about restricting the liquidity of their stakes when the asymmetric information problem between the market and inside investors is greatest. We argue that this information gap is affected by a number of characteristics. These include the sequence number of the fund, the geographic location of the fund, and the type of assets that the fund manages, e.g., buyouts versus venture capital. These characteristics should in turn affect the tightness of transfer restrictions.

According to our model, contracts should be most restrictive for the initial funds that a private equity firm raises, since the firm does not have at this point an established track record of observable successes yet and thus the asymmetric information is most severe. Over time, more information about the quality of the private equity firm becomes available and it is less important to screen for the limited partners with fewer liquidity shocks. To test this conjecture, we will analyze how limited partnership terms change when private equity firms raise one or several follow-on funds. We would expect that restrictions on the LP's ability to transfer her stakes should become less stringent with each additional fund, because the information asymmetry with respect to the outside market is reduced. ${ }^{22}$

Another factor that might impact the amount of asymmetric information private equity firms face is the ease with which the underlying assets of the fund can be valued. Holding everything else constant, our model would predict that funds whose assets are more difficult to value by an outsider (i.e., those funds are more prone to asymmetric information) should have tighter transfer restrictions. One possible dimension along which the underlying assets of a private equity partnership

\footnotetext{
${ }^{21}$ We also repeated the analysis that follows below for individual, very prominent provisions, such as the GP's right to approve the LP status of the transferee. We find that the same patterns that are reported for the composite measures hold at the level of a single provision.

${ }^{22}$ One consideration that may make it harder for us to find any effects is the tendency for many private equity groups to simply "recycle" their partnership agreements from fund to fund, rather than carefully examining the appropriateness of the features. For examples of such contractual rigidity in other settings, see Pittmann (1991).
} 
may vary is between buyout and venture capital funds. Early-stage venture investments are more difficult to assess through traditional accounting-based measures of performance. But we cannot be too confident in making this assumption. In many cases, venture capitalists invest in substantial portfolios of firms in a few industries (e.g., Internet commerce, telecommunications). The success or failure of these funds may largely depend on the fortunes of the individual sectors. Meanwhile, many buyout funds are dominated by a few large investments. It may be hard for outsiders to assess how these particular firms are faring. A second dimension along which partnership assets can vary is the industry focus. Funds that invest in businesses that take a long time before they produce observable results are prone to increased information asymmetries. Therefore, we classify funds according to four classes of industries: pharmaceutical industry, business services, telecommunications, and computing/Internet. We posit that start-ups in the pharmaceutical industries take a much longer time before they have observable products than start-ups in Internet-related businesses.

An important caveat with this approach is that for the funds that we observe in the economy, the type of assets they invest in (buyout deals versus venture capital and the industry focus) is a choice variable. Imagine private partnerships have different, unobserved abilities to alleviate asymmetric information problems with respect to the broader market. If the funds optimally choose the type of investments that are most suited to their type, in equilibrium we might not observe any difference in the liquidity of partnership stakes between the funds. A similar story might be told for the regional differences between California and the East Coast. We think, however, that for fund location, the self-selection problem is less severe, since their existing local networks largely prevent general partners from freely moving between locations. Given these limitations of the data and the analysis, the empirical results should be treated as only suggestive evidence for our theory.

Finally, our model also implies that in environments in which information is transferred more easily, we should observe fewer restrictions on liquidity. Of course, it is very difficult to measure or even observe differences of information diffusion, and any proxy for these must obviously be coarse and incomplete. One potential dimension along which the informational environment of private equity funds varies is "local culture." A well-known study on this topic by Saxenian (1994) analyzes the social and informational networks between the Silicon Valley venture capital community and that of Massachusetts' Route 128. Her findings suggest that information is shared 
much more extensively and diffuses more rapidly in the close-knit Silicon Valley community than in Massachusetts. She attributes these differences to a distinction in the culture of communication between the two places.

To the extent that this difference materially affects the information sets of the actors in the different regions, we would expect that it should lead to more serious asymmetric information problems outside of California. For the question that we are analyzing in this study, the implications are straightforward. If asymmetric information problems are smaller for California funds, we should expect fewer restrictions on the transferability of limited partnership interests of funds based in California. Since we can observe the location of the private equity funds in our sample, we will be able to test this hypothesis. ${ }^{23}$ Of course, there might be a number of other factors why contracts have developed differently between California and the East Coast, but it is important to note that partnership law is quite uniform nation-wide, due to the widespread promulgation of the U.L.P.A.

\subsection{Results}

Table 3 provides a first look at the patterns in the use of transferability provisions in the limited partnership agreements. The cross-tabulations suggest that later funds raised by private equity groups tend to have more provisions that enhance the transfer of partnerships by LPs. But they also have more provisions that allow GPs to control the transfers. Limited partner-friendly terms also appear to be associated with early-stage venture funds, older groups, those based in California, and those established in the later years of the sample. Our interpretation of these patterns, however, must be cautious due to the univariate nature of these comparisons. Early-stage venture funds, for instance, may differ from others along many dimensions, and it may be some other consideration that is most critical.

To test these hypotheses through regression analyses, we estimate the following baseline model:

$$
\begin{aligned}
\text { composite }_{i j t} & =\alpha * \text { sequ }_{i j t}+\beta * \log (\text { size })_{i j t} \\
& +\lambda * \text { buyout }+\delta * \text { early }+\gamma_{t}+\omega_{j}+\epsilon_{i j t}
\end{aligned}
$$

The different composite measures of transferability that were discussed in Section 4 are regressed

\footnotetext{
${ }^{23}$ It should be acknowledged that many East Coast-based venture capital groups also have offices in California. But in general, venture organizations tend to make the bulk of their investments near their primary offices.
} 
on the sequence number of the fund, dummy variables indicating whether a partnership raises a buyout or early stage venture capital fund, and controls for the size of the fund, as measured by the logarithm of committed capital. We also include year fixed effects (the year the fund had its final closing) and in some regressions fixed effects for each private equity organization. All standard errors are corrected for heteroscedasticity and clustered at the private equity group level.

Table 4 presents the results using the composite measure of transferability as the dependent variable. The coefficient on the sequence variable is large and statistically significant, with a point estimate of 0.09 and a standard error of 0.04 in the first column. At the mean of the independent variables, a one standard deviation increase in fund sequence translates into a 15 percent increase in the composite measure of transferability. As the second column suggests, the relationship between the ease of transferability and the sequence number of the fund remains robust when additional independent variables are added. One exception is when the year in which the private equity organization was established (the age of the private equity group) is added as an independent variable. This measure is strongly negatively correlated with the fund sequence variable. When added to the regression it leads to a decline in the magnitude and significance of the sequence variable. Column 3 shows that the coefficient goes down to 0.06 with a standard error of 0.05 . In fact, if we include the age of the private equity partnership by itself without controlling for the sequence number of the fund we find a negative coefficient, which is economically and statistically very significant (not reported in the paper). This suggests that younger private equity firms have more transfer constraints, which is consistent with our hypothesis that firms with a shorter track record must be more concerned about asymmetric information problems. We think, however, that the sequence number of the fund is a more accurate proxy of information asymmetry, since it reflects the amount of prior information that is available for each fund.

We isolate the longitudinal variation in the third and fourth columns, where we employ fixed effects for each private equity group. The within-firm specification allows us to control for unobserved differences across private equity firms. Thus, we can estimate the longitudinal effect on transfer constraints when a private equity firm raises its second, third, and later funds. Since private equity firms very rarely change between different sub-classes (for example moving from buyout to early stage investing is challenging indeed) the coefficients on the buyout and early stage dummies are estimated off of very few data points. Therefore, these measures are not meaningful in this speci- 
fication. We repeat the estimation in the fifth column, leaving out these variables. Again, we see that the sign of the sequence variable is positive and statistically significant and the magnitude of the coefficient is basically unchanged from the fourth column.

Unfortunately, we cannot apply this within-firm estimation to the cross sectional tests of whether the location (California versus Massachusetts) or the industry focus of the partnership matter for the transferability of stakes. Virtually no funds change the location of their headquarters during the time period. (This pattern is not unique to the funds in our sample, but rather a common feature of the industry.) Therefore, it is impossible to measure the effect of changes in these characteristics on the transferability of partnership stakes.

Instead, we use simple cross-sectional tests to estimate the correlation between the liquidity of partnership shares and the observable characteristics of interest, such as the location of the fund. In all these estimations, we also include year fixed effects. To assess the potential impact of fund-specific heterogeneity on the coefficients of these dummy variables, we re-estimate the results while subsequently including a number of fund-specific variables, and analyze how they affect these coefficients. If the size of the coefficients on the variables of interest does not change much after including additional control variables, we can feel more comfortable that these results are not purely driven by unobserved, fund-specific heterogeneity.

Column 5 of Table 4 shows that the coefficient on the California dummy is positive and significant, while the other regional dummies are insignificant. California private equity funds are less concerned about transfers of their partnership stakes than the average private equity firm. In the sixth column, we include control variables for the logarithm of fund size and dummies for buyout versus venture funds. Even after including these covariates, the size of the coefficient on the California dummy does not change significantly. It is statistically significant in all specifications and the point estimate of the coefficient goes down by only 15 percent, from 2.86 to 2.45 . If the coefficient on the California dummy was purely driven by unobservable heterogeneity between funds, we would expect the size of this coefficient to be smaller and statistically less significant once we include the other cross-sectional controls. The idea is that if the main source of variation between California and East Coast firms is the unobservable heterogeneity, including additional firm-specific controls should capture some of this underlying heterogeneity, and therefore, the significance of the initial variable would be reduced. 
The interpretation of the difference between buyout and venture funds in the transferability of partnership interests is less clear-cut. Table 4 shows that the coefficients on the dummies for earlystage venture funds are significantly positive, and those for buyout funds negative and sometimes significant. As above, we also analyzed how the coefficient changes with the addition of other control variables in unreported regressions. In general, and quite differently from the effects on the location dummies, we find that the significance and the size of the coefficient of the buyout and venture dummies are reduced with each additional control variable. Our confidence in these results is further shaken by the analysis when controls for limited partner type are added to the regressions: as discussed below, the magnitude and significance of the fund type measures fall sharply.

Finally, we include dummies for the different industry foci of the private equity funds. Column 7 shows that funds with a focus on the pharmaceutical industry have significantly more transfer constraints than the average. Similarly, funds that specialize in computing and Internet ventures have many fewer constraints than the average fund. We believe that investment cycles in the pharmaceutical industries are particularly long. (By way of contrast, investment cycles in the Internet-related ventures have historically been especially short). Therefore, GPs in these sectors will be subject to information asymmetries for a prolonged time period. Consistent with our theory, these funds are more concerned about preventing transfers of equity stakes.

\subsection{Robustness Checks}

One might be concerned that our proposed composite measures weigh all provisions equally (restrictive, facilitating, and regulatory constraints), which might overstate or understate the importance of one of these categories relative to the other. For instance, on average there are more facilitating provisions than restrictive ones in our sample. If, however, restrictive provisions had more "bite" than others, a simple sum of the number of restrictions would overstate the ease of transferability of the partnership interests.

Therefore, in Table 5, we separate the contract provisions into those that facilitate and those that restrict transfers. Again we find evidence that supports our main hypothesis. The first and second columns report that the number of provisions that enhance fund transfers increase for later

funds. These results indicate that our findings are not simply driven by the dynamics of netting out the different types of provisions. We also rerun these two specifications excluding any provision 
that could be motivated by compliance with regulatory considerations, e.g. provisions that affect the tax status or partnership status of the fund. The results (not reported) are qualitatively unchanged relative to results reported in Table 5.

We also want to make sure that the changes in contract provisions are not purely driven by mere editorial changes in these contracts, but that they reflect substantive factors in the transferability of stakes. Ideally, we would like to obtain data of actual trades that happened or even attempted sales that are blocked. The data were impossible to collect. As the second-best alternative, we talked to lawyers specializing in private equity and consulted the related legal literature to determine which provisions are generally considered most important and restrictive. Provisions that give the general partners the right to approve of transfers and to prevent any transfer that conflicts with their interests are generally believed to be the most critical restrictions. The results using these most critical restrictions are reported in the third and fourth columns of Table 5. Parallel to the prior results, we find that the coefficient on the sequence variable is negative and significant when firm fixed-effects are used. In follow-on funds, the general partners' control over the transferability of partnership stakes is reduced significantly relative to earlier funds. ${ }^{24}$

\subsection{Interpreting the Results}

We are cautious to emphasize that the results in this section should be viewed as suggestive evidence for the theoretical framework that we have developed in the paper, but they cannot provide an ultimate proof of the model developed in Section 3. Obviously, there are a large number of potential omitted variables in our estimation that we cannot control for, partly because they are truly unobservable and partly because of the serious restrictions in the disclosure of information in the private equity industry.

We believe that the positive relationship between the ease of transferability and the sequence number of the private equity fund (estimated based on within-group changes) is the strongest evidence in support of our theory. Most alternative stories for transfer restrictions would imply either a negative coefficient on the sequence variable or no effect. An alternative theory that has

\footnotetext{
${ }^{24}$ In Table 5, we also report for the sake of completeness regression analyses using the measure of contractual complexity as the independent variable. We also separately estimate for each of the contract provisions a probability model (not reported here) on the likelihood of being included in later funds. Consistent with the findings of the composite measures, we observe that for restrictive provisions the probability of being included in the contract declines over time, and vice versa for facilitating provisions.
} 
been mentioned is that general partners want to reduce the liquidity of their stakes to avoid the transaction costs of raising capital in future rounds. Even though this theory could explain why there might be transfer restrictions in the first place, it cannot easily predict the dynamic effects that we document. In fact, if we assume that the value of the general partners' time increases over time, since they have more outside opportunities, we would actually predict the opposite sign.

Finally, it is particularly striking that transfer constraints are less stringent for follow-on funds, if we consider that the bargaining power between limited partners and funds shifts towards the general partners once these have been able to establish a track record. For example, Gompers and Lerner (1996) show that older funds tend to have more GP-friendly terms of all kinds. In this paper, however, the authors do not analyze the role of transfer constraints, but focus on many of the contract provisions that affect the moral hazard between the limited and general partners. The reduction of transfer constraints over time therefore seems to be an important point of LP bargaining. Moreover, it is important to keep in mind that any industry-wide changes in bargaining power (these could be due to shifts in the supply and demand of capital) will not affect our estimates, since we are controlling for year fixed effects in all our specifications.

\section{$5 \quad$ Looking at Limited Partner Composition}

In this section, we analyze whether the identity of the limited partners that invest in a private equity fund is related to the transferability of the stakes. Our theory predicts that the ease of transferability should be higher when limited partners are less likely to be affected by liquidity shocks.

We collect data from the Private Equity Analyst on the identity of LPs for the funds in our sample. This is the only publicly available source for this type of information, but unfortunately there are several limitations to this data set. We are able to obtain information for only 84 of our 250 funds, since many firms do not disclose this information to the magazine. Moreover, the Private Equity Analyst only started collecting this data in 1991, while several of the funds in our sample were raised in the 1970s and 1980s. The actual dollar amounts invested by the LPs are not

reported. Finally, the Private Equity Analyst does not provide a complete list of LPs invested in each fund. Since private equity partnerships do not have to report this information to securities 
or other regulators, the disclosure to the magazine is voluntary and varies between funds and over time. For example, we cannot distinguish actual changes in the set of limited partners in a follow-on fund from improvements in the completeness of reporting. Therefore, we will restrict our analysis in this section to a cross-sectional test, since we do not feel comfortable relying on longitudinal variation of changes in limited partner stakes. ${ }^{25}$.

We classify LPs into several categories that are commonly used to describe private equity limited partners: universities, foundations, pension funds, banks, corporations, and funds-of-funds (intermediaries who commingle capital from a variety of institutional and individual investors and invest it in private equity funds). Generally, participants in the private equity industry consider universities and endowments as the most sophisticated, long-horizon investors. In contrast, pension funds and corporations are considered much more ephemeral in their commitment to the private equity industry, since they change their investment strategy more often (see Gompers and Lerner (1999b), chapter 5). In the terminology of our model, universities and endowments would be the investors with a low probability of a liquidity shock, while corporations and pension funds have a higher propensity of facing liquidity shocks. For each fund, we calculate the absolute number and the fraction of limited partners in each category.

We also use a second classification to measure the likelihood that a limited partner will be hit by a liquidity shock, since we believe that there is also a lot of variance within the LP categories. For example, while Harvard, MIT, and Yale are highly sophisticated limited partners that have been investing in the asset class for several decades, many other universities have joined the trend only very recently. A similar argument holds for funds-of-funds: while many groups are recent arrivals with little experience, others are among the most experienced and sophisticated private equity investors.

Thus, we measure the sophistication and long-term commitment of different limited partners by whether they had a significant exposure to the asset class prior to the 1990s. The NACUBO guide (National, 2001) provides annual information on the portfolio allocation of universities. En-

\footnotetext{
${ }^{25}$ This limitation of the data is unfortunate, since it would be very interesting to analyze whether the pool of investors changes when a fund becomes older and more established. For example, one could imagine that established companies could either broaden their set of LPs once they grow or they become pickier in their choice of LPs. Anecdotally, it seems that many top LPs do not invest in first-round funds, but probably are earlier in identifying above-average performers in the industry, while unsophisticated LPs have a more difficult time investing in top private equity partnerships early on
} 
dowments that had more than five percent of their assets in non-marketable securities in 1990 are coded as sophisticated. We undertake a similar identification of sophisticated foundations based on general knowledge of their investment histories. Similarly, we use information from Pease (2000) to identify fund of funds that were started prior to 1990. Panel A of Table 6 shows the distribution of LPs.

In what follows, we want to test if the transferability of partnership interests varies with the limited partners of the fund. In particular we would like to see whether transferability is positively related to the fraction of long-horizon investors in the fund. Therefore, we repeat the cross-sectional tests from the previous section including measures of the fraction of limited partners in each asset class:

$$
\begin{aligned}
\text { composite }_{i j t} & =\alpha * X_{i j t}+\beta * \text { univ }_{i j t}+\lambda * \text { foundation }_{i j t}+\delta * \text { bank }_{i j t}+\gamma * \text { corp }_{i j t} \\
& +\pi * \text { pension }_{i j t}+\omega * f \text { und }- \text { of }- \text { fund }_{i j t}+\epsilon_{i j t}
\end{aligned}
$$

We include the same control variables $X_{i j t}$ as in the earlier regressions, as well as year dummies. All standard errors are corrected for heteroskedasticity and clustered at the firm level. We also repeat the tests, using the count or share of sophisticated investors rather than the different limited partner classes.

Table 6 shows the results from the regressions when we include the limited partner classifications. As the first and third columns report, we observe that for funds with a higher fraction of foundations among their limited partners, the composite measure of limited partner-friendly transferability terms is significantly higher. The coefficients on the rest of the limited partner dummies are not significant, but the signs go in the direction that we would expect. For example, universities and funds-of-funds are positive while banks, corporations, and pension funds are negative. The results are even stronger when we look (in unreported regressions) at the two alternative measures of transferability analyzed in Table 5 .

Another interesting result in this analysis is that the magnitude of the coefficients on the earlystage and buyout dummy variables falls dramatically once we control for the composition of limited partners. The difference in transferability of venture and buyout fund seems critically related to the mix of investors that choose to invest into these different funds. This suggests that, consistent with 
arguments above, there is a matching process, where private equity organizations find appropriate investors.

We repeat these estimations with our measure of sophisticated (long-term) limited partners. A higher value of this measure implies a lower probability of a liquidity shock happening, since these investors have shown long-term commitment to the asset class. Consistent with the previous results, we find in the fourth column of Table 6 that funds that have a larger fraction of long-horizon limited partners allow the transfer of partnership stakes more freely. (The pattern is similar in magnitude in the second column, but not statistically significant. We believe, however, that the specification in the fourth column of Table 6 is preferable, since it measures the fraction of investors that can be classified as "sophisticated" limited partners.)

These results are consistent with the major implications of our model. If transfer restrictions are used to screen for investors with deep pockets, these provisions will be less important when the likelihood of a liquidity shock is low for certain types of investors. We hasten to say that the evidence presented in this section is prone to potential measurement error, due to the small sample size and the data collection problems discussed in the beginning of this section. Nonetheless, this analysis, which we hope to expand and improve in future research, provides a set of suggestive results.

\section{Conclusion}

This paper examines the rationales for restrictions on liquidity. It suggests an alternative to the governance-based rationale traditionally offered for such curbs, focusing on the private equity in-

dustry. The model suggests that imposing restrictions on the liquidity of investor ownership stakes may enable managers, in our case GPs of private equity groups, to influence the composition of investors. We explicitly model liquidity constraints as a choice variable that allows the GP to alleviate the adverse selection problem in follow-on fund raising by screening for "deep pocket" investors.

We test these predictions in the context of the private equity industry. We find that consistent with our theory, funds that are less prone to asymmetric information have fewer transfer constraints. For example, later funds of the same private equity firm have fewer transfer constraints, consistent 
with the idea that these funds are less affected by information asymmetries, since the firm has established a track record. Moreover, funds that operate in industries with longer investment cycles have more constraints. Also, funds in the close-knit California private equity environment have fewer constraints than East Coast funds, where information supposedly travels slower.

The applications of these ideas are much broader and more general than the private equity setting. Many corporate finance transactions impose restrictions that are in excess of what are required by securities law. Exploring the extent to which some of these same rationales may be at work is a natural extension of this analysis. An understanding of these issues, however, is particularly urgent in the private equity industry. In the past few years, there has been a surge of interest on the part of limited partners in liquidating their holdings. In some cases, these groups have sought to reduce their overall exposure to private equity; in other instances, they have sought to garner "dry powder" for further private equity investments (for a discussion, see Toll, 2000). As the theoretical analysis above suggests, such moves have the potential to have very positive features, but also to impose substantial costs. Thus, gaining a better understanding of the tradeoffs associated with liquidity is important to academics and practitioners alike. 


\section{References}

Asset Alternatives, 2001, Galante's Venture Capital and Private Equity Directory, Wellesley, Massachusetts: Asset Alternatives (and earlier years).

Bhide, Amar, 1993, The Hidden Costs of Stock Market Liquidity, Journal of Financial Economics $34,31-51$.

Burr, Stephen I., 1982, The Potential Liability of Limited Partners as General Partners, Massachusetts Law Review 67, 22-34.

Capital Publishing Company, various years, SBIC/Venture Capital Reporter, Chicago: Capital Publishing Company (also known as SBIC Reporter).

Faure-Grimaud, Antoine, and Denis Gromb, 1999, Public Trading and Private Incentives, Unpublished Working Paper, London School of Economics and Massachusetts Institute of Technology.

Feld, Alan L., 1969, The 'Control' Test for Limited Partnerships, Harvard Law Review 82, 1471-.

Gilberg, David J., 1986, Regulation of Financial Instruments Under the Federal Securities and Commodities Law, Vanderbilt Law Review 39, 1599-1669.

Gompers, Paul A., and Josh Lerner, 1996, The Use of Covenants: An Empirical Analysis of Venture Partnership Agreements, Journal of Law and Economics 39, 463-498.

Gompers, Paul A., and Josh Lerner, 1999a An Analysis of Compensation in the U.S. Venture Capital Partnership, Journal of Financial Economics 51, 3-44.

Gompers, Paul A., and Josh Lerner, 1999b, The Venture Capital Cycle, Cambridge: MIT Press.

Grossman, Sanford J., and Oliver D. Hart, 1980, Takeover Bids, the Free-Rider Problem, and the Theory of the Corporation, Bell Journal of Economics 11, 42-64.

Harroch, Richard D., 1998, Start-Up and Emerging Companies, New York: Law Journal SeminarsPress.

Holmström, Bengt, and Jean Tirole, 1993, Market Liquidity and Performance Monitoring, Journal of Political Economy 101, 678-709.

Liles, Patrick R., 1977, Sustaining the Venture Capital Firm, Cambridge: Management Analysis Center.

Loss, Louis, and Joel Seligman, 1995, Fundamentals of Securities Regulation, Third edition, Boston: Little, Brown.

McKee, William S., William F. Nelson, and Robert L. Whitmire, 1997, Federal Taxation of Partnerships and Partners, Third edition, Boston: Warren, Gorman, and Lamont.

National Association of College and University Business Officers, 2001, NACUBO Endowment Study, Washington: NACUBO (and earlier years).

Pease, Robert, 2000, Private Equity Fund-of-Funds: State of the Market, Wellesley, Massachusetts: Asset Alternatives. 
Pittman, Russell, 1991, Specific Investments, Contracts, and Opportunism: The Evolution of Railroad Sidetrack Agreements, Journal of Law and Economics 34, 565-589.

Saxenian, AnnaLee, 1994, Regional Advantage: Culture and Competition in Silicon Valley and Route 128, Cambridge: Harvard University Press.

Scharfstein, David S., and Jeremy C. Stein, 2000, The Dark Side of Internal Capital Markets: Divisional Rent-Seeking and Inefficient Investment, Journal of Finance 55, 2537-2564.

Shleifer, Andrei, and Robert W. Vishny, 1986, Large Shareholders and Corporate Control, Journal of Political Economy 94, 461-488.

Toll, David M., 2000, Securitization of Asset Class Begins to Open Vast Sources of Capital, Private Equity Analyst 10, November, 60-64.

Venture Economics, 1995, Private Equity Fundraising Database, Unpublished computer file.

Venture Economics, 2001, Pratt's Guide to Venture Capital Sources, Newark: Venture Economics (and earlier years). 


\section{Appendix}

A major concern of private equity funds is to avoid coming under the provisions of the Investment Company Act of 1940 ('40 Act), which has been characterized as "one of the most complex and extensive of all the federal securities statutes." 26 One of the four major securities acts enacted during the period of "New Deal" reforms initiated by President Franklin Roosevelt, it sought to regulate mutual funds and other instruments for pooled investments in securities. The act imposes detailed regulations governing almost every aspect of investment companies' operations, including reporting requirements, governance provisions, and demands for detailed record keeping.

Anticipating that investment companies might seek to avoid these requirements, the drafters of the act developed two central tests as to what constituted an investment company. A company would be regarded as an investment firm if it satisfied one of two tests. These were if it "is or holds itself out as being engaged primarily, or proposes to engage primarily, in the business of investing, reinvesting or trading in securities," 27 or "owns or proposes to acquire investment securities having a value exceeding 40 per centum of the issuer's total assets (exclusive of Government securities and cash items)." 28

Almost every private equity group would fall under these rules, which would essentially make the type of investing practiced by most groups impossible, were it not for an exception established by the drafters of the act (and its subsequent amendments). The act exempts funds whose securities are owned by less than 100 "accredited investors" (those with $\$ 200,000$ in annual net income for the past two years and expected in the current year or $\$ 1$ million in net worth) and intend to remain privately held. (This exemption is often referred as the "Rule of 99" in private equity circles.) In 1996, this requirement was amended to allow these partnerships to accept funds from an unlimited number of "super qualified" investors (those with more than $\$ 5$ million of investable assets). The need to avoid coming under the provisions of the act have provided a powerful spur to private equity organizations to control transfers of partnership interests. Nonetheless, as discussed below, the level of control over transferability in these agreements is far in excess of what would be required to comply with securities law.

Tax considerations also play a role. Section 708(b)(1)(B) of the Internal Revenue Code, first enacted in 1954, limits such exchanges. Motivated by the desire to avoid sales of partnership interests for tax avoidance purposes, this statute states that a partnership terminates if "within a 12-month period there is a sale and exchange of 50 percent or more of the total interest in partnership capital and profits." This has been interpreted as limiting the annual sum of all transfers - whether between limited partners or with third parties - to less than 50 percent. (Exceptions are made for, among other cases, gifts, bequests, and transfers between divorcing spouses.)

A second set of tax regulations is even more binding. Since 1987, partnerships that are "traded

\footnotetext{
${ }^{26}$ Gilberg (1986) (quote on page 1632). For a more general discussion of this act, see Loss and Seligman (1995).

${ }^{27} 15$ United States Code @80a-3(a)(1)(A)

${ }^{28} 15$ U.S.C. @80a-3(a)(1)(C).
} 
in an established securities market" or "readily tradable on a secondary market or the substantial equivalent thereto" ${ }^{29}$ may be designated publicly traded partnerships (also known as master limited partnerships). The central test is whether the trading volume in these partnership interests on such exchanges exceeds 2 percent of the pool's capital or profit share. Publicly traded partnerships are generally treated as corporations for income tax purposes - i.e., earnings are taxed at the entity as well as the partner level, rather than just at the partner level - which is highly disadvantageous to the partners.

\footnotetext{
${ }^{29}$ Reg. 1.7704-1(a)(1). The definition of these markets is very intricate. For example, trading of partnership interests through qualified matching services do not trigger a characterization of a fund as a publicly traded partnership, as long as the total annual volume of shares traded on all exchanges is less than 10 percent (McKee, et al., 1997).
} 


\begin{tabular}{|c|c|c|c|c|}
\hline$\overline{I I}$ & $\overline{\overline{0}}$ & & $6 \varepsilon^{\circ} 0$ & 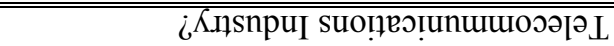 \\
\hline I & 0 & & $8 z^{\circ} 0$ & ¿Səつ!̣.JəS ssəu!̣sng \\
\hline I & 0 & & $2 \nabla^{*} 0$ & 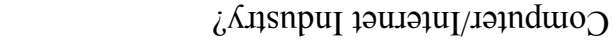 \\
\hline I & 0 & & $\angle t^{\circ} 0$ & 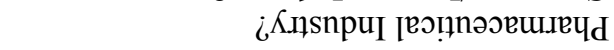 \\
\hline I & 0 & & $\varsigma \mathcal{E}^{\circ} 0$ & 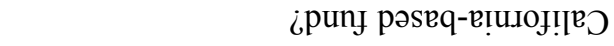 \\
\hline I & 0 & & SIㅇ 0 & ¿punj pəseq-צıIo $\Lambda$ MәN \\
\hline I & 0 & & $9 \tau^{\circ} 0$ & ¿puny pəseq-sңəsnчәеsseW \\
\hline I & 0 & & $\varsigma \mathcal{E}^{\circ} 0$ & 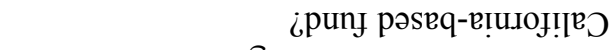 \\
\hline $\mathrm{I} 002$ & $t L 6 \mathrm{I}$ & $9^{\circ} 9$ & Z66I & 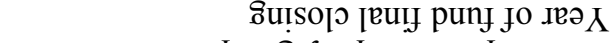 \\
\hline $000 z$ & $9+6 \mathrm{I}$ & I.6 & I86 I & 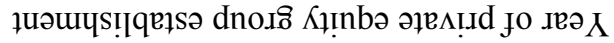 \\
\hline 0.00 I9 & $\varsigma^{\varsigma} 0 \mathrm{I}$ & $t .8 L L$ & $8 \cdot I S t$ & 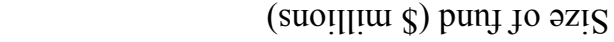 \\
\hline I & 0 & & $6 I^{\circ} 0$ & ¿puny tnokng \\
\hline I & 0 & & $0 \varepsilon^{\circ} 0$ & 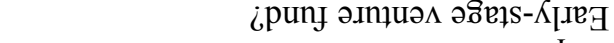 \\
\hline $\begin{array}{l}9 \mathcal{E} \\
\text { unшuฺxp } W\end{array}$ & I & $\begin{array}{l}6 \triangleright t \\
\text { uo!ฺp!na }\end{array}$ & $\begin{array}{l}t \cdot S \\
\text { unวW }\end{array}$ & punj јо әэuәnbəs \\
\hline
\end{tabular}

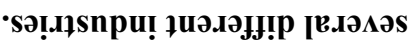

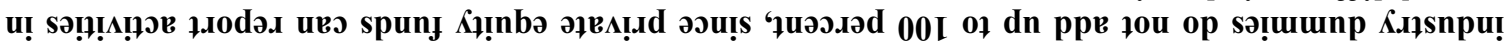

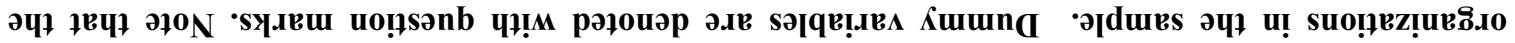

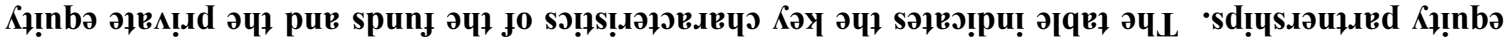

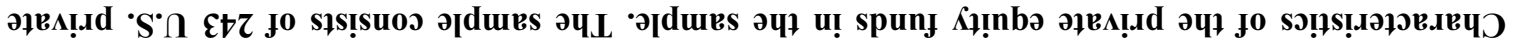

I ग्व' $\mathbf{L}$ 


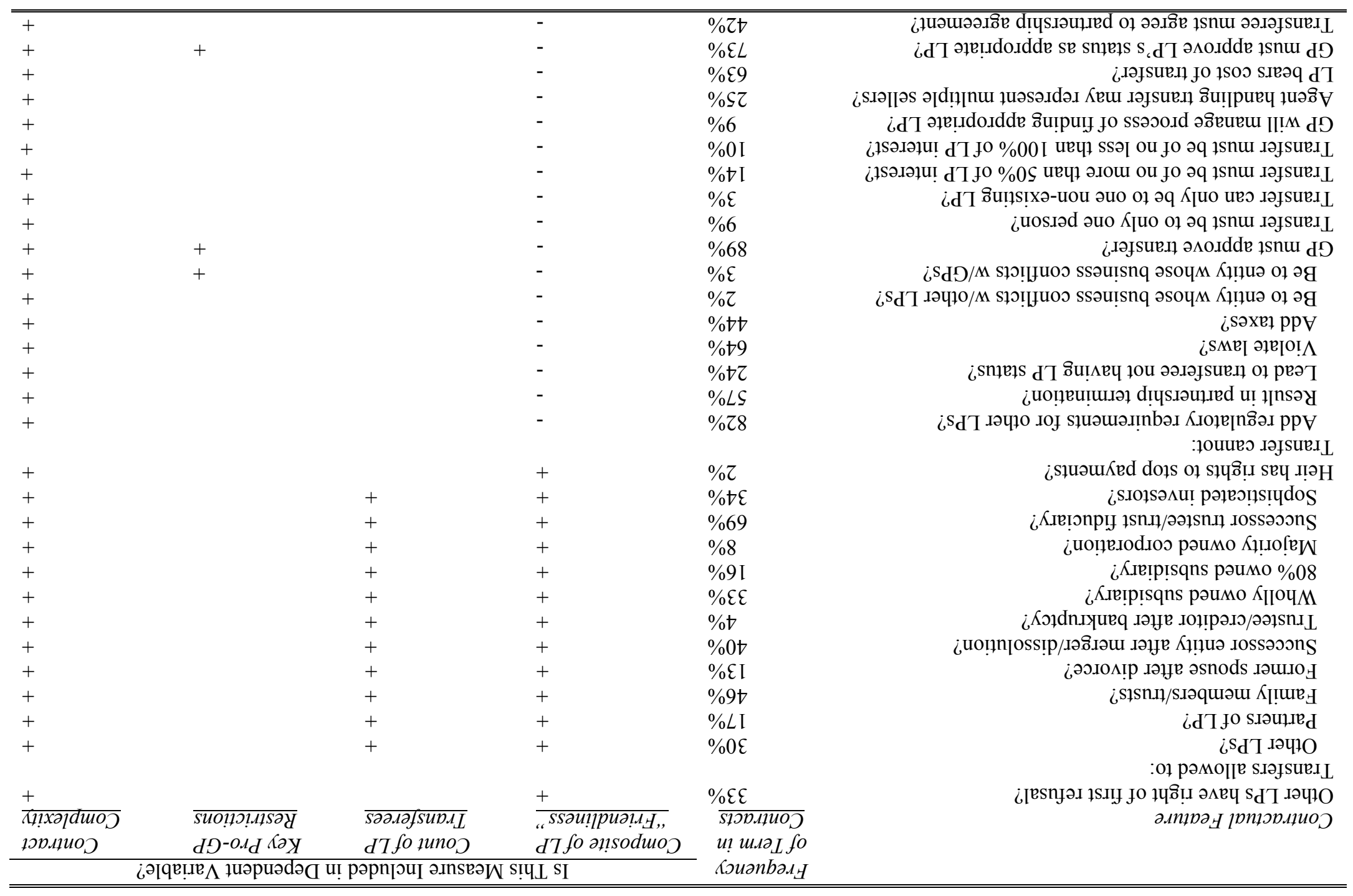

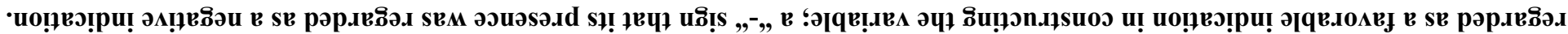

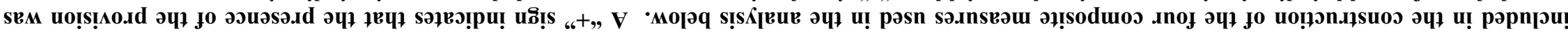

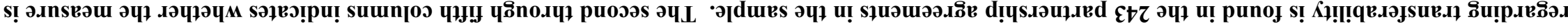

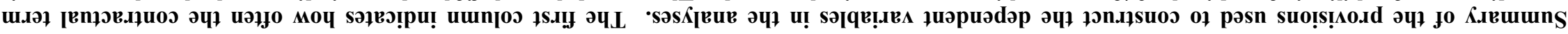




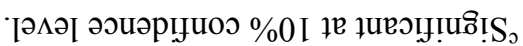

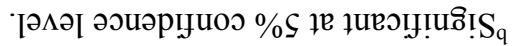

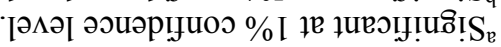

\begin{tabular}{|c|c|c|c|c|}
\hline$\overline{z S^{\circ} 0}$ & $\bar{n} t \varsigma^{\circ} \mathcal{E}$ & $\overline{{ }_{q} \varepsilon t^{\prime} \cdot \tau}$ & $\overline{0} 0 Z^{\prime} Z$ & 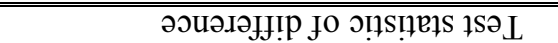 \\
\hline $20 \circ 0 \mathrm{I}$ & $0 S^{*} \mathrm{I}$ & It॰ $\varepsilon$ & $\tau L \cdot \mathcal{E}$ & 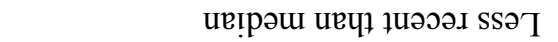 \\
\hline$\varsigma Z^{\circ} 0 \mathrm{I}$ & $L L^{\prime} I$ & $89^{\circ} \tau$ & $88^{\circ} \tau$ & 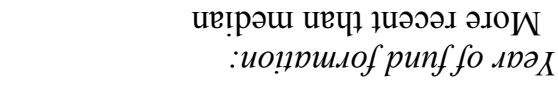 \\
\hline $29^{\circ} 0$ & ${ }_{0} \mathcal{E} L^{\prime} I$ & $t t^{\circ} I$ & ${ }^{\circ} 6 L^{\circ} \mathrm{I}$ & 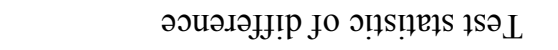 \\
\hline $80 \circ 0 \mathrm{I}$ & Z9. I & $8 I^{\circ} \varepsilon$ & $6 \varepsilon^{\circ} \varepsilon$ & $\mathrm{oN}$ \\
\hline $69 \cdot 6$ & I8. I & $8 \varsigma^{\prime} \tau$ & $\angle t r$ & $\begin{array}{r}\operatorname{s}{ }_{X} \\
: p u n f y \mu o_{X} \text { маN }\end{array}$ \\
\hline $68^{\circ} \varepsilon$ & $9 \tau^{\prime} \tau$ & ${ }_{R} \angle 0^{\circ} \varsigma$ & $6 I^{\circ} \mathcal{E}$ & 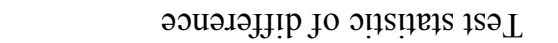 \\
\hline IS'0I & $0 L^{\circ} \mathrm{I}$ & IS'E & $6 \varsigma^{\circ} \varepsilon$ & $\mathrm{oN}$ \\
\hline $29^{\circ} 8$ & IS $S^{*}$ & $68^{\circ} \mathrm{I}$ & $8 \tau^{\circ} \tau$ & $\begin{array}{r}\operatorname{sa}_{X} \\
\text { :punf shasnyopssw } W\end{array}$ \\
\hline $809^{\circ} \mathrm{L}$ & $t t^{\circ} 0$ & ${ }_{\mathrm{e}} \mathrm{S} \mathbf{7}^{\circ} \mathrm{P}$ & $80 \% 8$ & 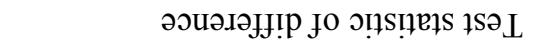 \\
\hline I6.8 & $99^{\circ} \mathrm{I}$ & $8 Z^{\circ} Z$ & $8 \tau^{\circ} \tau$ & $\mathrm{oN}$ \\
\hline$\varsigma_{0}{ }^{\circ} \mathrm{I}$ & $\varepsilon 9^{\circ} \mathrm{I}$ & $\angle S^{\prime} t$ & $\varepsilon 0^{\circ} \varsigma$ & 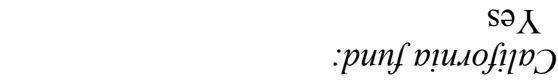 \\
\hline$\downarrow \varepsilon^{*} \mathrm{I}$ & $\angle 8^{\circ} 0$ & ${ }_{\mathrm{B}} \mathcal{S} \varsigma^{*} \dagger$ & ${ }_{\varepsilon} \mathcal{E} L^{*} \mathcal{E}$ & 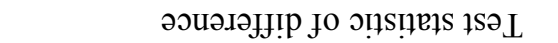 \\
\hline It॰0I & $09^{\circ} \mathrm{I}$ & $I L^{*} \mathcal{E}$ & $66^{\circ} \mathcal{\varepsilon}$ & 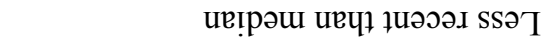 \\
\hline $08 \%$ & $\angle 9^{\circ} \mathrm{I}$ & $\angle \varepsilon^{\prime} \tau$ & $09^{\circ} \tau$ & 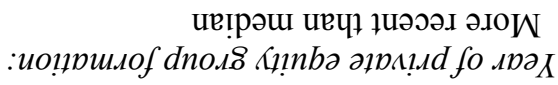 \\
\hline $6 \mathrm{I}^{*} 0$ & ${ }_{\mathrm{q}} L S^{\prime} \tau$ & $8 \varsigma^{\circ} \mathrm{I}$ & $\varepsilon I^{*} I$ & 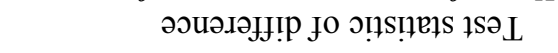 \\
\hline $60^{\circ} 0 \mathrm{I}$ & $\varepsilon \varsigma^{\circ} \mathrm{I}$ & $0 \varepsilon^{*} \varepsilon$ & $\varepsilon \varsigma^{\cdot} \varepsilon$ & ив!рәш мојә् \\
\hline LI*0I & $\varepsilon L^{*} I$ & $28^{\circ} \mathrm{Z}$ & $0 I^{\circ} \varepsilon$ & 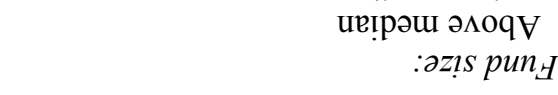 \\
\hline$\rightarrow \varepsilon \cdot \tau$ & $\varsigma \varepsilon^{*} 0$ & ${ }_{8} 9 t^{\circ} \varepsilon$ & ${ }_{t} t \varepsilon \cdot t$ & 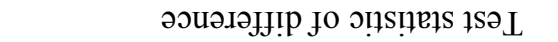 \\
\hline $9 Z^{\circ} 0 \mathrm{I}$ & $99^{\circ} \mathrm{I}$ & $\varepsilon \varepsilon^{\cdot} \varepsilon$ & $\tau 9^{\circ} \varepsilon$ & $\mathrm{oN}$ \\
\hline 968 & $29^{\circ} \mathrm{I}$ & t0. & $\nabla 9^{\circ} \mathrm{I}$ & $\begin{array}{r}\operatorname{so}_{X} \\
\text { :punftnoKng }\end{array}$ \\
\hline${ }_{e} \varepsilon 0^{\circ} t$ & I I'0 & ${ }_{\mathrm{B}} \tau L^{\circ} \varepsilon$ & ${ }_{\mathrm{E}} \mathrm{II}^{\circ} \mathrm{S}$ & 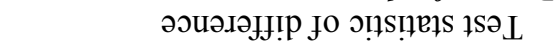 \\
\hline $9 t^{\circ} 6$ & ९9. I & $t L^{\prime} Z$ & $\angle 9^{\circ} Z$ & $\mathrm{oN}$ \\
\hline$\varepsilon \varepsilon^{*} \mathrm{I}$ & $t 9^{\circ} \mathrm{I}$ & $06^{\circ} \mathcal{E}$ & $29^{\circ} t$ & 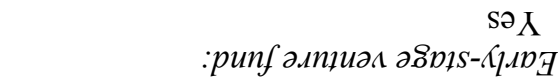 \\
\hline$\Delta 6 \cdot \tau$ & ${ }_{\mathrm{e}} \varsigma 9^{\circ} \mathcal{\varepsilon}$ & $66{ }^{\circ} 2$ & ${ }_{0} \mathrm{~L} 6^{\circ} \mathrm{I}$ & 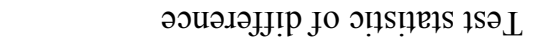 \\
\hline $6 t^{\circ} 6$ & $0 S^{\prime} \mathrm{I}$ & $\varepsilon 9^{\circ} \tau$ & $\angle 6 \cdot 2$ & четрәш морәЯ \\
\hline $08^{\circ} 0 \mathrm{I}$ & $8 L^{\circ} \mathrm{I}$ & $\varepsilon \varsigma^{\circ} \mathcal{\varepsilon}$ & $69^{\circ} \varepsilon$ & 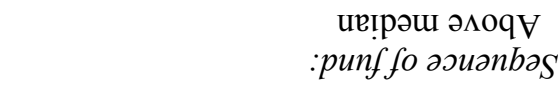 \\
\hline 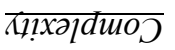 & 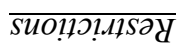 & 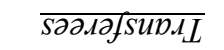 & 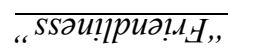 & \\
\hline ฉорициоว & $d D^{-0 . I_{d}}$ KəУ & 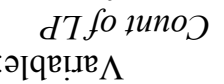 & d7 fo әи!soduо & \\
\hline
\end{tabular}

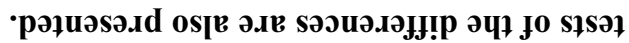

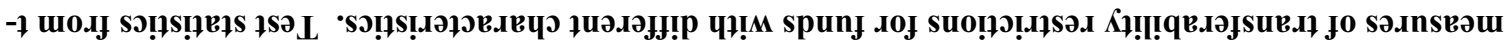

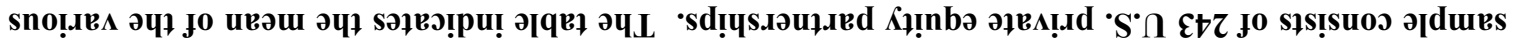

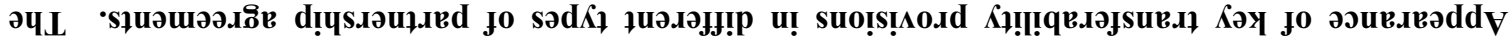

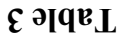




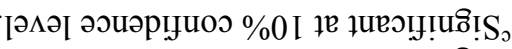

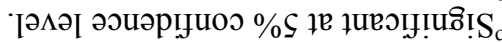

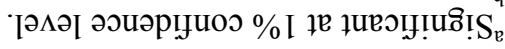

\begin{tabular}{|c|c|c|c|c|c|c|c|}
\hline Z†॰0 & $\varsigma Z^{\circ} 0$ & $\varepsilon Z^{\circ} 0$ & $78^{\circ} 0$ & $\angle I^{\circ} 0$ & $\angle I^{\circ} 0$ & $\angle I^{\circ} 0$ & г $\mathrm{d}$ pəџsn!p \\
\hline $000^{\circ} 0$ & $000^{\circ} 0$ & $000^{\circ} 0$ & $100^{\circ} 0$ & $000^{\circ} 0$ & $000^{\circ} 0$ & $000^{\circ} 0$ & әn ${ }^{\mathfrak{e}} \Lambda-\mathrm{d}$ \\
\hline$I \varepsilon^{*} \nabla$ & $89^{\circ} \mathcal{\varepsilon}$ & $\tau \varsigma^{\circ} \varepsilon$ & $\angle \nabla^{*} Z$ & $0 L^{\prime} Z$ & $0 L^{\circ} Z$ & $Z L^{\prime} Z$ & 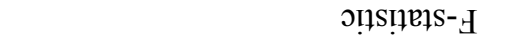 \\
\hline$\varepsilon \varepsilon Z$ & $\varepsilon \oplus Z$ & $\varepsilon \oplus Z$ & $\varepsilon \nabla \tau$ & 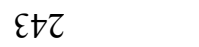 & $\varepsilon \nabla \tau$ & $\varepsilon \nabla \tau$ & 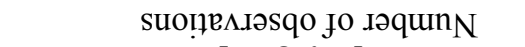 \\
\hline $\mathrm{ON}$ & $\mathrm{oN}$ & $\mathrm{oN}^{\mathrm{N}}$ & $\operatorname{se} \Lambda$ & $\mathrm{oN}$ & $\mathrm{oN}$ & $\mathrm{oN}$ & 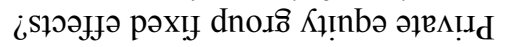 \\
\hline $\operatorname{son} \Lambda$ & $\operatorname{so} \Lambda$ & $\operatorname{se} \Lambda$ & $\operatorname{se} \Lambda$ & $\operatorname{sex}$ & $\operatorname{se} \Lambda$ & $\operatorname{se} \Lambda$ & 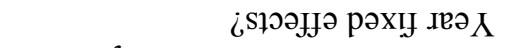 \\
\hline$\left[69^{\circ} 0\right] \angle Z^{\circ} 0^{-}$ & & & & & & & 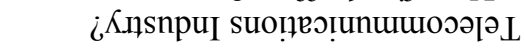 \\
\hline${ }_{\mathrm{e}}\left[\varsigma 9^{\circ} 0\right] 06^{\circ} \mathrm{I}$ & & & & & & & ¿səo!n.JəS ssəu!sng \\
\hline$\left[\angle 9^{\circ} 0\right] 0 \varepsilon^{\circ} I^{-}$ & & & & & & & 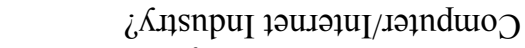 \\
\hline${ }_{\mathrm{q}}\left[\varsigma 9^{\circ} 0\right] \nabla \varepsilon^{\circ} \mathrm{I}^{-}$ & & & & & & & 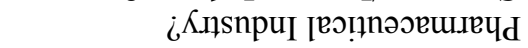 \\
\hline$\left[69^{\circ} 0\right] 8 L^{\circ} 0$ & {$\left[\mathrm{I} 9^{\circ} 0\right] 08^{\circ} 0$} & {$\left[09^{\circ} 0\right] \mathrm{IS}^{*} 0$} & & & & & ¿рunf צ.ı X MәN \\
\hline$\left[9 \varsigma^{\circ} 0\right] \tau \varepsilon^{\bullet} 0$ & {$\left[t \varsigma^{*} 0\right] 6 \varepsilon^{\circ} 0$} & {$\left[\varsigma \varsigma^{\circ} 0\right] \varsigma \tau^{\circ} 0$} & & & & & ¿рunj słəsnчэеsseW \\
\hline${ }_{\mathrm{B}}\left[\varsigma \varsigma^{*} 0\right] \nabla \varepsilon^{\cdot} \tau$ & ${ }_{\mathrm{p}}\left[\varepsilon \varsigma^{*} 0\right] \varsigma \nabla^{*} Z$ & ${ }_{\mathrm{e}}\left[Z \varsigma^{*} 0\right] 98^{\circ} \tau$ & & & & & 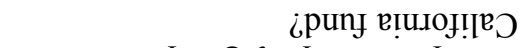 \\
\hline & & & & {$\left[z 0^{\circ} 0\right] \varepsilon 0^{\circ} 0^{-}$} & {$\left[z 0^{\circ} 0\right] \varepsilon 0^{\circ} 0^{-}$} & & 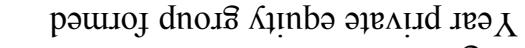 \\
\hline & & & {$\left[I Z^{\bullet} 0\right] \varepsilon \varepsilon^{\cdot} 0^{-}$} & {$\left[z z^{\circ} 0\right] 9 \tau^{*} 0$} & {$\left[z z^{\circ} 0\right] 9 z^{\circ} 0$} & {$\left[z \tau^{*} 0\right] \tau \varepsilon^{\cdot} 0$} & 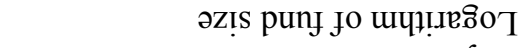 \\
\hline$\left[t \varsigma^{*} 0\right] 6 \varsigma^{\circ} 0^{-}$ & {$\left[z \varsigma^{\circ} 0\right] 69^{\circ} 0^{-}$} & & {$\left[8 \varsigma^{\circ} 0\right] \mathrm{I}^{\circ} 0$} & ${ }_{\mathrm{q}}\left[L \varsigma^{*} 0\right] \nabla \mathcal{E}^{*} \mathrm{I}^{-}$ & ${ }_{\mathrm{q}}\left[L S^{*} 0\right] \nabla \mathcal{E}^{\cdot} \mathrm{I}^{-}$ & ${ }_{e}\left[9 \varsigma^{\circ} 0\right] 6 t^{\circ} \mathrm{I}^{-}$ & punf łnoKng \\
\hline${ }_{q}\left[\varepsilon t^{*} 0\right] 06^{\circ} 0$ & ${ }_{q}\left[z \nabla^{*} 0\right] z 6^{\circ} 0$ & & {$\left[87^{\circ} 0\right] 20^{\circ} 0^{-}$} & ${ }_{[}^{1}\left[\varepsilon t^{\circ} 0\right] Z 9^{\circ} \mathrm{I}$ & ${ }_{\mathrm{B}}\left[\varepsilon \nabla^{\circ} 0\right] z 9^{\circ} \mathrm{I}$ & ${ }_{\mathrm{v}}\left[\varepsilon \nabla^{\circ} 0\right] 99^{\circ} \mathrm{I}$ & 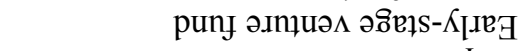 \\
\hline${ }_{0}\left[t 0^{\circ} 0\right] 80^{\circ} 0$ & ${ }_{0}\left[t 0^{\circ} 0\right] 80^{\circ} 0$ & 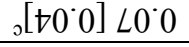 & $\left.{ }_{\mathrm{e}}\left[\varsigma 0^{\circ} 0\right]\right\rangle \mathrm{I}^{\circ} 0$ & {$\left[\varsigma 0^{\circ} 0\right] 90^{\circ} 0$} & {$\left[\varsigma 0^{\circ} 0\right] 90^{\circ} 0$} & ${ }_{q}\left[t 0^{\circ} 0\right] 60^{\circ} 0$ & punf Jo әэuәnbəS \\
\hline
\end{tabular}

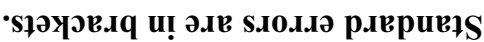

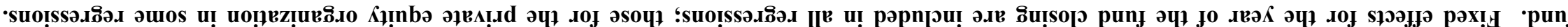

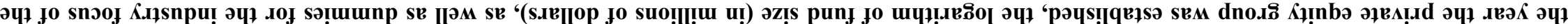

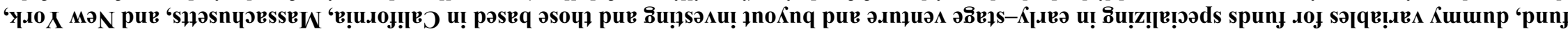

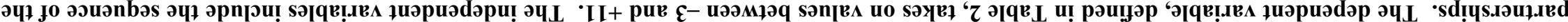

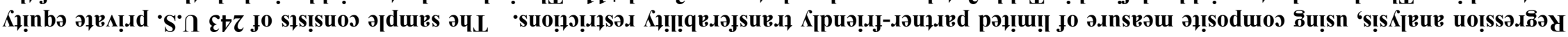




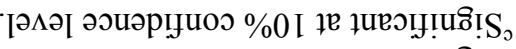

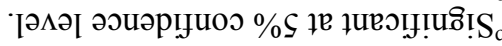

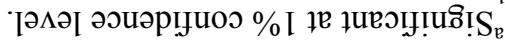

\begin{tabular}{|c|c|c|c|c|c|c|}
\hline $06^{\circ} 0$ & ZI'0 & $S L O 0$ & $t I^{\circ} 0$ & $\varepsilon 6^{\circ} 0$ & ZI०0 & ${ }_{\tau} \mathrm{Y}$ pəłsn!p \\
\hline $000^{\circ} 0$ & $100^{\circ} 0$ & $000^{\circ} 0$ & $000^{\circ} 0$ & $000^{\circ} 0$ & $200^{\circ} 0$ & әn $\boldsymbol{e}^{\mathrm{e}} \Lambda^{-\mathrm{d}}$ \\
\hline $00^{\circ} 8$ & $6 I^{\circ} Z$ & $0 z^{*} t$ & $6 \varepsilon^{\cdot} \tau$ & $\angle 9^{\circ} \mathcal{E}$ & $\varepsilon I^{\cdot} Z$ & 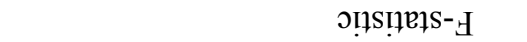 \\
\hline$\varepsilon \succ \tau$ & $\varepsilon \succsim \tau$ & $\varepsilon \neq \tau$ & $\varepsilon \ni \tau$ & $\varepsilon \neq \tau$ & $\varepsilon \neq \tau$ & 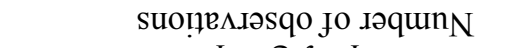 \\
\hline $\operatorname{se} \Lambda$ & $\mathrm{oN}$ & $\operatorname{so} \Lambda$ & $\mathrm{ON}$ & $\operatorname{son} X$ & $\mathrm{oN}$ & 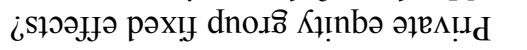 \\
\hline $\operatorname{san}$ & $\operatorname{so} X$ & $\operatorname{se} \lambda$ & $\operatorname{so} \lambda$ & $\operatorname{se} \lambda$ & $\operatorname{so} \lambda$ & 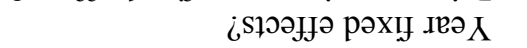 \\
\hline$\left[0 Z^{\circ} 0\right] \varsigma I^{*} 0^{-}$ & {$\left[9 \tau^{\circ} 0\right] 0 \tau^{*} 0$} & {$\left[\varsigma 0^{\circ} 0\right] \mathrm{I}^{\circ} 0$} & {$\left[t 0^{\circ} 0\right] \varsigma 000^{\circ} 0^{-}$} & ${ }_{\mathrm{e}}\left[\mathrm{II} \mathrm{I}^{\circ} 0\right] 9 \mathcal{E}^{\circ} 0^{-}$ & {$\left[8 \mathrm{I}^{\circ} 0\right] 8 \mathrm{I}^{\circ} 0$} & 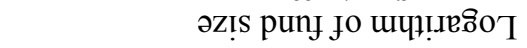 \\
\hline$\left[9 \varsigma^{\circ} 0\right] \angle t^{\circ} 0^{-}$ & ${ }_{\curvearrowright}\left[89^{\circ} 0\right] 0 Z^{*} \mathrm{I}^{-}$ & {$\left[\varsigma I^{\circ} 0\right] \nabla Z^{*} 0^{-}$} & ${ }_{q}\left[Z I^{*} 0\right] \varepsilon Z^{*} 0^{-}$ & {$\left[\varepsilon^{\bullet} 0\right] 90^{\circ} 0$} & {$\left[9 t^{\circ} 0\right] 9 L^{\circ} 0^{-}$} & punj znokng \\
\hline$\left[9 \nabla^{\circ} 0\right] \varepsilon I^{\circ} 0^{-}$ & ${ }_{\mathrm{p}}\left[\mathrm{Z \varsigma ^{ \circ }} 0\right] \mathrm{Z9^{ \circ } \mathrm { I }}$ & {$\left[\varepsilon\left[^{\circ} 0\right] t 0^{\circ} 0\right.$} & {$\left[60^{\circ} 0\right] 60^{\circ} 0^{-}$} & {$\left[\varsigma \tau^{\circ} 0\right] 80^{\circ} 0$} & ${ }_{\mathrm{p}}\left[9 \varepsilon^{\circ} 0\right] 0 \tau^{*} \mathrm{I}$ & 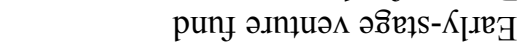 \\
\hline${ }_{\mathrm{e}}\left[\varsigma 0^{\circ} 0\right] \nabla \mathrm{I}^{\circ} 0$ & {$\left[\varsigma 0^{\circ} 0\right] 80^{\circ} 0$} & ${ }_{\mathrm{q}}\left[\mathrm{I} 0^{\circ} 0\right] \varepsilon 0^{\circ} 0^{-}$ & {$\left[\mathrm{I0} 0^{\circ} 0\right] \mathrm{Z00} 0$} & ${ }_{\curvearrowright}\left[\varepsilon 0^{\circ} 0\right] \varsigma 0^{\circ} 0$ & ${ }_{0}\left[\varepsilon 0^{\circ} 0\right] 90^{\circ} 0$ & punf Jo əəuənbəS \\
\hline \multicolumn{2}{|c|}{ 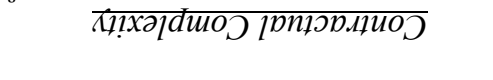 } & 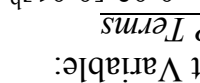 & 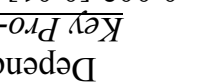 & \multicolumn{2}{|c|}{ sadafsupdL dTfo ұuno } & \\
\hline
\end{tabular}

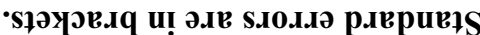

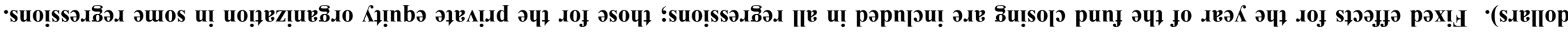

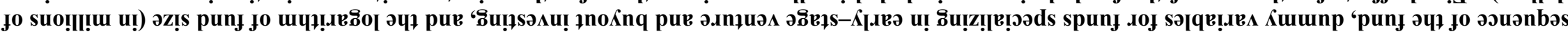

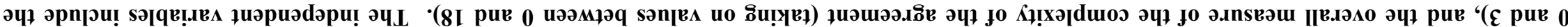

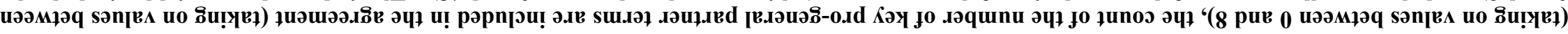

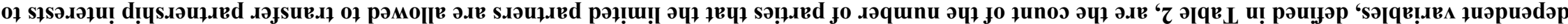

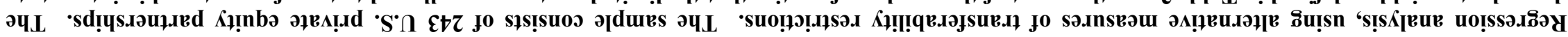




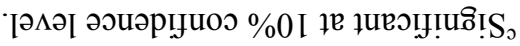

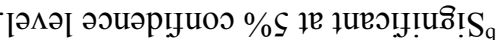

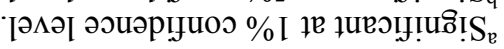

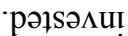

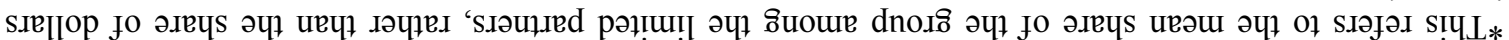

\begin{tabular}{|c|c|c|c|c|}
\hline $87^{\circ} 0$ & $8 t^{\circ} 0$ & $6 \varepsilon^{\circ} 0$ & $6 \varepsilon^{\circ} 0$ & 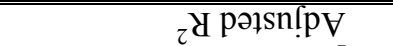 \\
\hline $000^{\circ} 0$ & $000^{\circ} 0$ & $000^{\circ} 0$ & $000^{\circ} 0$ & әпүе $\Lambda_{\Lambda}^{-d}$ \\
\hline $78^{\circ} \varsigma$ & $s t \boldsymbol{t}$ & $\nabla \varepsilon \cdot \nabla$ & $8 \varepsilon^{\cdot} \varepsilon$ & 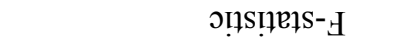 \\
\hline 78 & 78 & 78 & 78 & 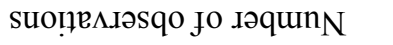 \\
\hline $\operatorname{son} \lambda$ & $\operatorname{so} X$ & so $X$ & so $X$ & 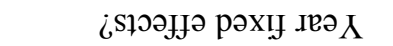 \\
\hline \multirow[t]{8}{*}{${ }_{\mathrm{e}}\left[60^{\circ} 0\right] \dagger \varepsilon^{*} 0$} & & \multicolumn{2}{|l|}{$\left[87^{\circ} \mathrm{I}\right] 66^{\circ} \mathrm{I}$} & 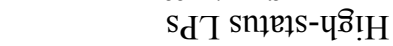 \\
\hline & {$\left[97^{\circ} 0\right] \mathrm{ZO}^{\circ} 0^{-}$} & & {$\left[8 \tau^{\cdot} \mathcal{\varepsilon}\right] \angle \mathcal{E}^{\cdot} \tau$} & 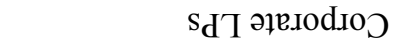 \\
\hline & ${ }_{\mathrm{q}}\left[6 \tau^{\circ} 0\right] 6 \varsigma^{\circ} 0$ & & ${ }_{\curvearrowright}\left[\varepsilon 8^{*} \varepsilon\right] 0 \varsigma^{*} 9$ & s $_{\mathbf{d T}}$ uo!̣ppuno \\
\hline & {$\left[\varepsilon I^{\circ} 0\right] Z I^{\circ} 0^{-}$} & & {$\left[Z \varsigma^{\circ} I\right] 6 \tau^{\circ} 0$} & sdT punf uoỊsuə $_{\mathbf{d}}$ \\
\hline & {$\left[z 8^{\circ} 0\right] \mathrm{IZ} \mathrm{Z}^{\circ} 0$} & & {$\left[\varepsilon 0^{\circ} 6\right] 6 L^{\circ} \mathrm{L}$} & 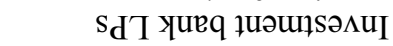 \\
\hline & {$\left[\varepsilon \varepsilon^{\circ} 0\right] 97^{\circ} 0^{-}$} & & {$\left[I^{\circ}+\right]^{\circ} 6^{\circ} \mathrm{I}^{-}$} & $s_{\mathbf{d}}$ y yueg \\
\hline & {$\left[07^{\circ} 0\right] 8 I^{\circ} 0$} & & {$\left[96^{\circ} \mathrm{I}\right] 9 \varsigma^{\circ} \mathrm{I}$} & sd $_{\mathbf{d}}$ punf-Jo-pun $_{\mathfrak{H}}$ \\
\hline & {$\left[Z \mathrm{I}^{\circ} 0\right] 8 \mathrm{I}^{\circ} 0$} & & {$\left[6 t^{\circ} I\right] 8 \varsigma^{\circ} I$} & s \\
\hline$\left[8 \varepsilon^{*} 0\right] Z^{*} 0^{-}$ & {$\left[\varsigma \nabla^{\circ} 0\right] 6 \varepsilon^{\circ} 0^{-}$} & {$\left[z \nabla^{\circ} 0\right] 9 t^{\circ} 0^{-}$} & {$\left[0 \varsigma^{*} 0\right] S L^{\cdot} 0^{-}$} & 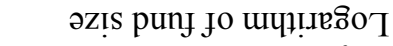 \\
\hline$\left[t L^{\circ} 0\right] 88^{\circ} 0^{-}$ & {$\left[6 L^{\circ} 0\right] 68^{\circ} 0^{-}$} & {$\left[08^{\circ} 0\right] 06^{\circ} 0^{-}$} & {$\left[06^{\circ} 0\right] \varepsilon 9^{\circ} 0^{-}$} & puny $\mathfrak{x}$ oאng \\
\hline$\left[z 9^{\circ} 0\right] \angle \tau^{\circ} 0$ & {$\left[\angle 9^{\circ} 0\right] \varepsilon \varepsilon^{\circ} 0$} & {$\left[\varepsilon L^{\circ} 0\right] \varepsilon t^{\cdot} 0$} & {$\left[S L^{\circ} 0\right] 6 \varepsilon^{\circ} 0$} & 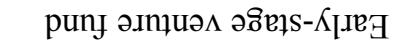 \\
\hline${ }_{\mathrm{p}}\left[90^{\circ} 0\right] 07^{\circ} 0$ & ${ }_{\mathrm{q}}\left[\angle 0^{\circ} 0^{\circ}\right] \angle \mathrm{I}^{\circ} 0$ & ${ }_{\mathrm{e}}\left[\angle 0^{\circ} 0\right] \varsigma Z^{\circ} 0$ & ${ }_{\mathrm{e}}\left[80^{\circ} 0\right] \varepsilon \tau^{\circ} 0$ & punf Jo əəuənbəs \\
\hline \multicolumn{4}{|c|}{ 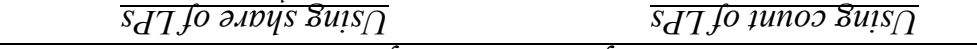 } & \\
\hline \multicolumn{5}{|c|}{ 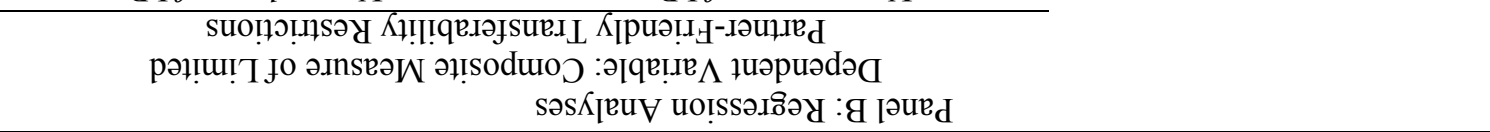 } \\
\hline \multicolumn{2}{|l|}{$\% 92$} & \multicolumn{2}{|l|}{$0^{\circ} \varepsilon$} & 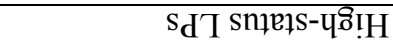 \\
\hline \multicolumn{2}{|l|}{$\% 9$} & \multicolumn{2}{|l|}{$8^{\circ} 0$} & 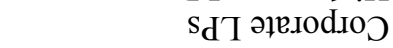 \\
\hline \multicolumn{2}{|l|}{$\% \varsigma$} & \multicolumn{2}{|l|}{$L^{\circ} 0$} & sdT uọฺpuno $_{\mathbf{H}}$ \\
\hline \multicolumn{2}{|l|}{$\% L I$} & \multicolumn{2}{|l|}{$L \cdot I$} & sd puny uọsuəd \\
\hline \multicolumn{2}{|l|}{$\% \mathrm{I}$} & \multicolumn{2}{|l|}{$I^{\circ} 0$} & 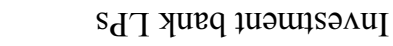 \\
\hline \multicolumn{2}{|l|}{$\% \varepsilon$} & \multicolumn{2}{|l|}{$t^{*} 0$} & sd Үurg \\
\hline \multicolumn{2}{|l|}{$\%$ ZI } & \multicolumn{2}{|l|}{$\varepsilon \cdot I$} & s $_{\mathbf{d}}$ punf-Jo-pun \\
\hline \multicolumn{2}{|l|}{$\%$ \% } & \multicolumn{2}{|l|}{$9 \cdot \tau$} & sd \\
\hline \multirow[t]{3}{*}{ * ग.DYYS } & \multirow{2}{*}{\multicolumn{3}{|c|}{ 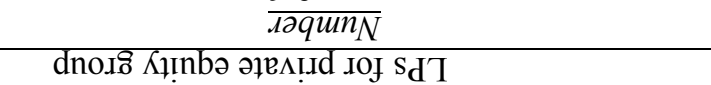 }} & 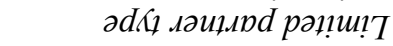 \\
\hline & & & & \\
\hline & \multicolumn{3}{|c|}{ 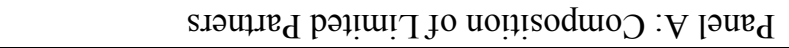 } & \\
\hline
\end{tabular}

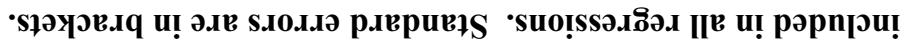

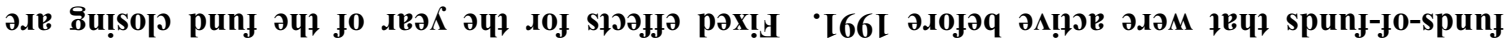

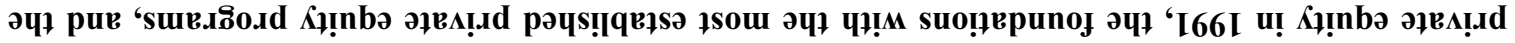

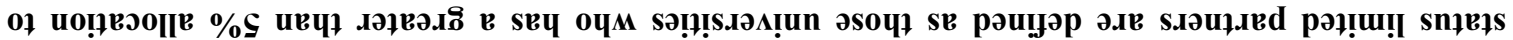

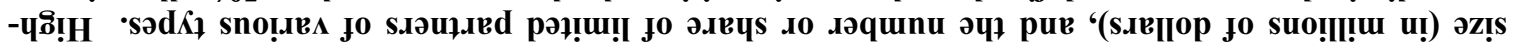

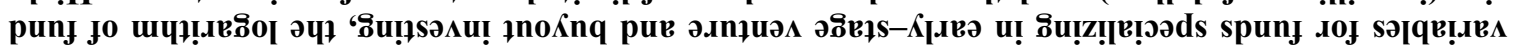

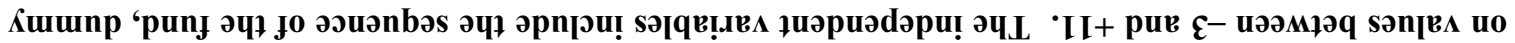

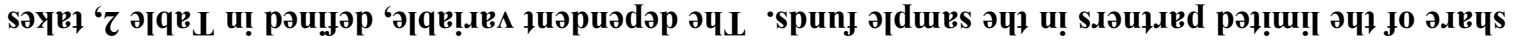

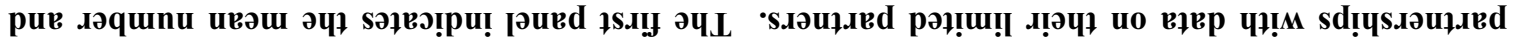

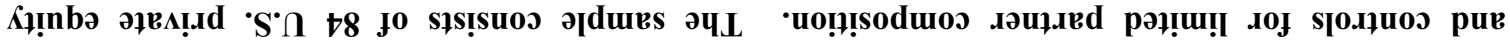

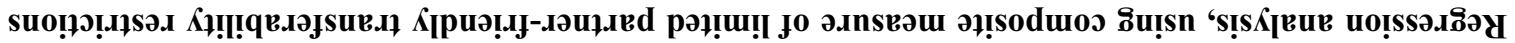

